University of Nebraska - Lincoln

DigitalCommons@University of Nebraska - Lincoln

June 1964

\title{
PHYTOTOXIC SUBSTANCES FROM SOIL MICROORGANISMS AND CROP RESIDUES
}

T.M. McCalla

Soil and Water Conservation Research Division, United States Department of Agriculture, and Nebraska Agricultural Experiment Station, University of Nebraska, Lincoln, Nebraska

F.A. Haskins

Soil and Water Conservation Research Division, United States Department of Agriculture, and Nebraska Agricultural Experiment Station, University of Nebraska, Lincoln, Nebraska

Follow this and additional works at: https://digitalcommons.unl.edu/usdaarsfacpub

Part of the Agricultural Science Commons

McCalla, T.M. and Haskins, F.A., "PHYTOTOXIC SUBSTANCES FROM SOIL MICROORGANISMS AND CROP RESIDUES" (1964). Publications from USDA-ARS / UNL Faculty. 21.

https://digitalcommons.unl.edu/usdaarsfacpub/21

This Article is brought to you for free and open access by the U.S. Department of Agriculture: Agricultural Research Service, Lincoln, Nebraska at DigitalCommons@University of Nebraska - Lincoln. It has been accepted for inclusion in Publications from USDA-ARS / UNL Faculty by an authorized administrator of DigitalCommons@University of Nebraska - Lincoln. 


\title{
PHYTOTOXIC SUBSTANCES FROM SOIL MICROORGANISMS AND CROP RESIDUES ${ }^{1}$
}

\author{
T. M. McCalla and F. A. Haskins
}

Soil and Water Conservation Research Division, U.S. Department of Agriculture, and Nebraska Agricultural Experiment Station, University of Nebraska, Lincoln, Nebraska

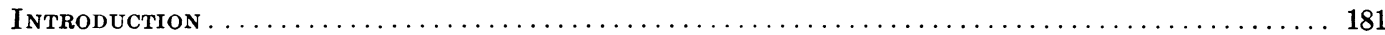

Soll Microbial Products Inhibitory to Microbial Growth $\ldots \ldots \ldots \ldots \ldots \ldots \ldots \ldots \ldots \ldots \ldots$

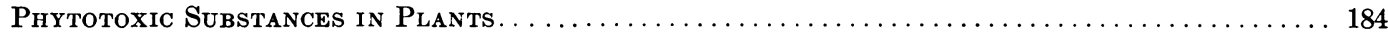

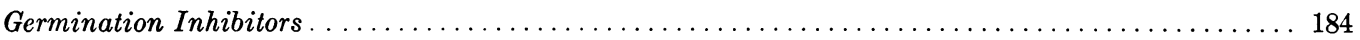

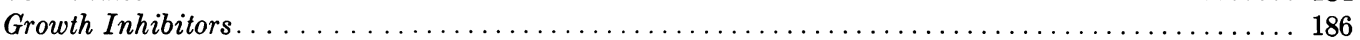

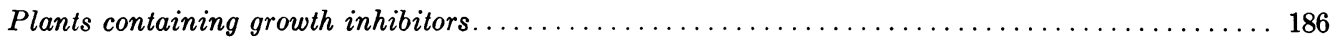

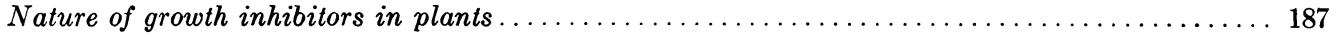

Early Work on Phytotoxic Substances Found in Plant Residues and Soil . . . . . . . . . . . . 187

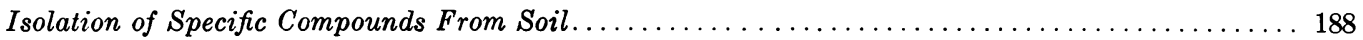

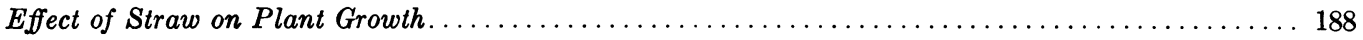

Recent Work on the Occurrence of Phytotoxic Substances in Soil and the Production of

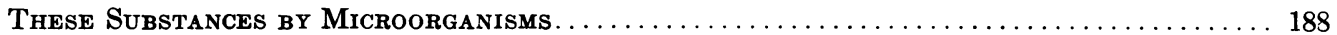

Influence of Certain Organic Compounds and Antibiotics on Plant Growth............. 188

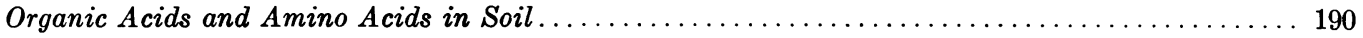

Influence of Carbon Dioxide, Bicarbonates, Nitrite, Hydrogen Sulfide, and Ammonia on Plant Growth. 191

Production of Phytotoxins by Soil Microorganisms and Plant Pathogens. . . . . . . . . . . . . . 192

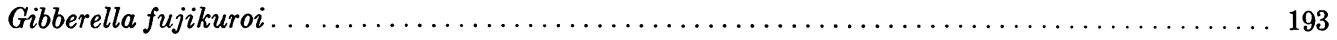

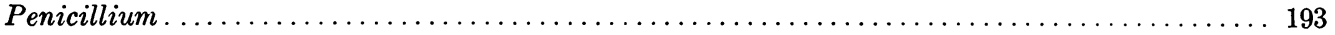

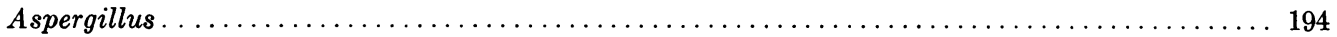

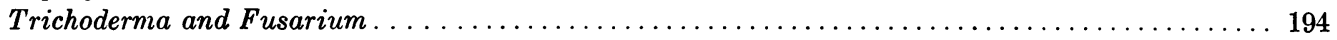

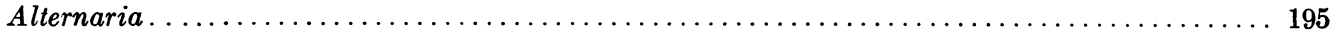

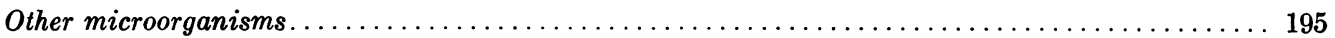

Phytotoxic Substances in Decomposing Plant Residues, Soil Organic Matter, and Soil. . . . . . . . . 195

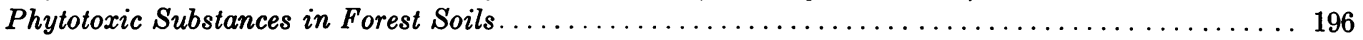

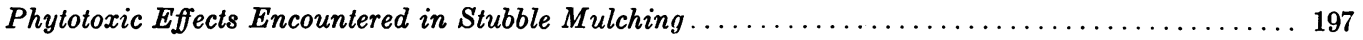

Some Specific Plant Effects Possibly Caused by Toxins From Microorganisms. . . . . . . . . . 198

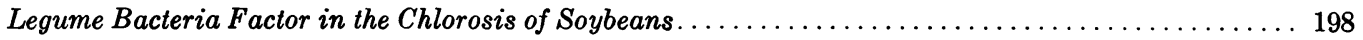

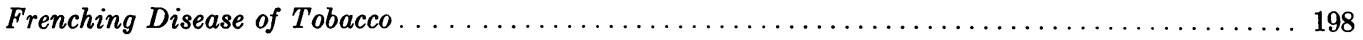

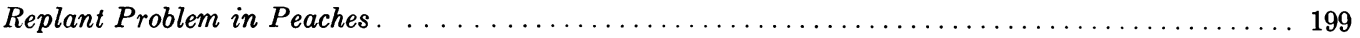

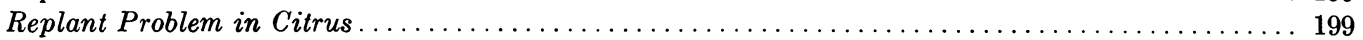

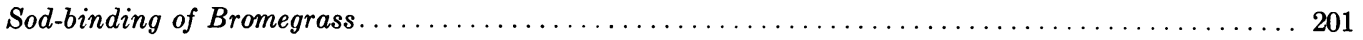

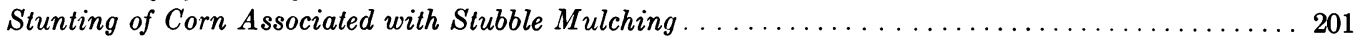

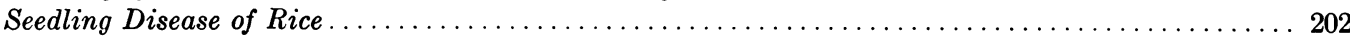

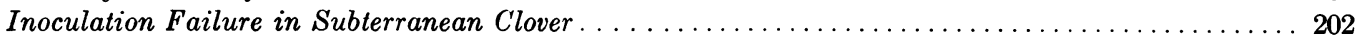

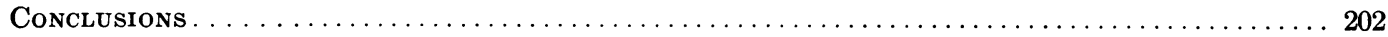

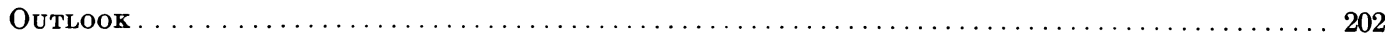

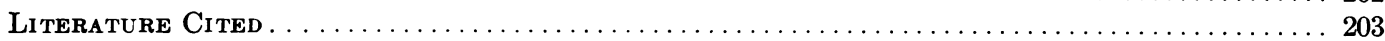

\section{INTRODUCTION}

The role of organic matter in the growth of plants has been a subject of much investigation and controversy since the sixteenth century. During the early era, decomposition of plant residues and green and animal manures provided a pri-

1 Published with the approval of the Director as Paper no. 1354, Journal Series, Nebraska Agricultural Experiment Station, Lincoln. mary source of minerals for plant growth. In addition, beneficial effects on soil structure and waterholding capacity were attributed to the presence of organic matter. With the development of agricultural chemistry culminating in the work of Liebig in the nineteenth century, it was discovered that plants could make satisfactory growth in the absence of added organic matter if suitable kinds and amounts of inorganic nutrients were supplied. However, persistent efforts were 
made by various investigators and lay groups to emphasize the important role of organic matter, rather than inorganic fertilizers, in soil fertility and plant growth. Because of the complexity of the problem and lack of suitable techniques, no satisfactory solution to the controversy was obtained during Liebig's time.

Since the Liebig era, frequent attempts have been made to determine in detail the influence of organic matter on plant growth. For example, develop normally with adequate supplies of inorganic nutrients, but they may also take up many organic substances which influence growth. In recent years, a renewed interest has developed in the role of these organic substances. This interest has been greatly stimulated by the availability of new techniques such as paper, gas, and column chromatography and infrared spectrophotometry which aid in the isolation and identification of organic compounds.

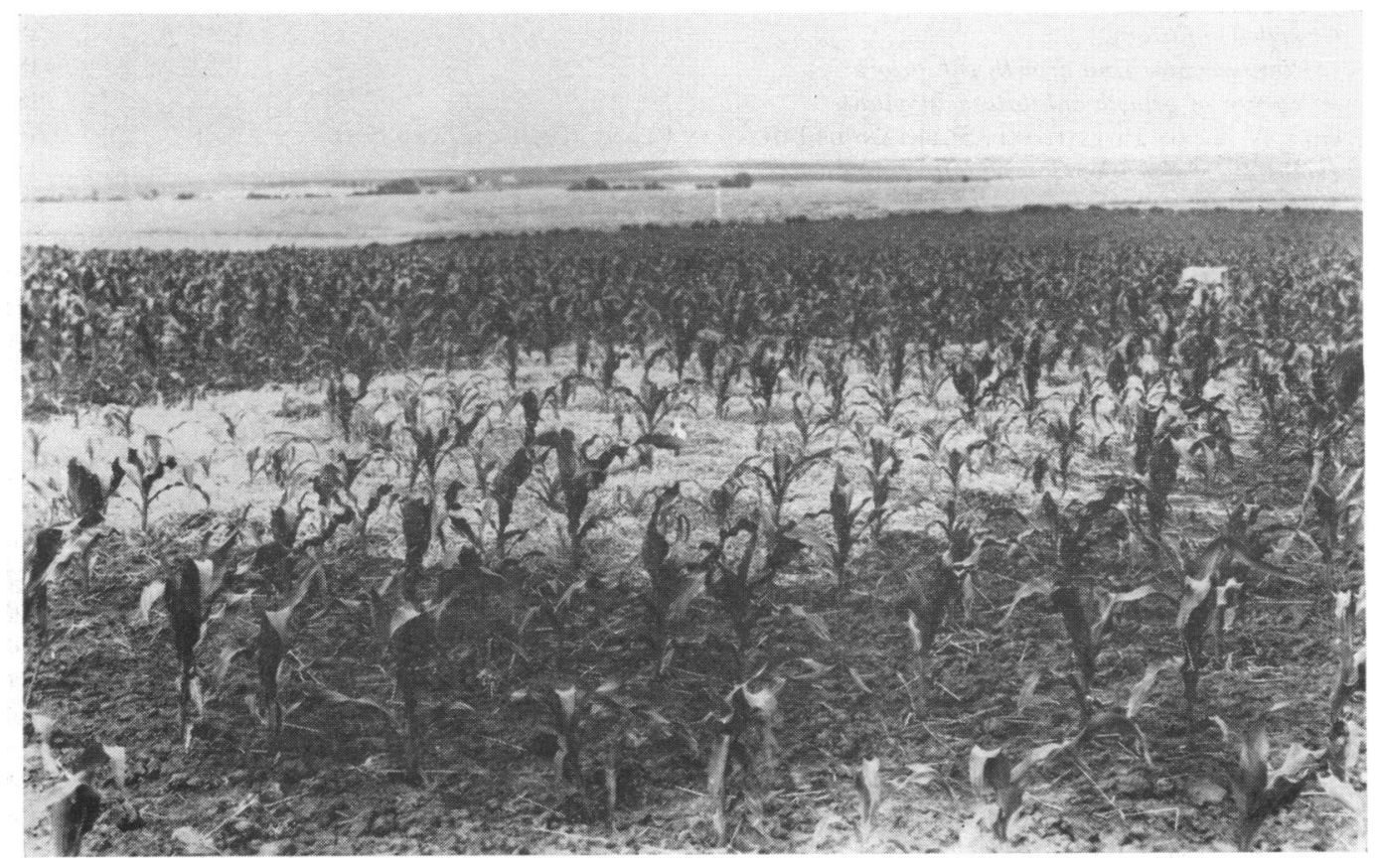

FIG. 1. Influence of stubble mulching with 8 tons of straw per acre on growth of corn at Lincoln, Neb. Note irregular growth of corn on mulched plot.

Schreiner and Shorey (113) attempted to explain the low productivity of some soils on the basis of certain toxic organic substances present. Dihydroxystearic acid and vanillin were isolated and shown to be toxic to plants in aqueous solution. However, it was shown that soil and fertilizers tend to neutralize the effect of these toxic substances. Since adequate mineral fertilization largely overcame the toxic effects of such compounds, most investigators doubted that organic substances in the soil had any important direct influence on plant growth. With the discovery and utilization of antibiotics and herbicides, there was a re-examination of this position. Plants may
Recent field observations disclosed the occurrence of reduced plant growth under the system of farming known as stubble mulching (Fig. 1). McCalla and Army (80) and others suggested that this effect was the result of toxic decomposition products of microorganisms or substances from plant residues. Similar observations of retarded plant growth encountered in citrus replant and peach tree replant, seedling inhibition and frenching of tobacco, sod-bound bromegrass, and reduced growth of forest tree seedlings in some instances add support to the belief that growth inhibitors may accumulate in the soil $(9,72,95$, $96,128)$. 
Certainly under field conditions, with heavy fertilization, large quantities of plant and animal residues are returned to the soil to decompose. Numerous organic and inorganic substances result from this decomposition. The concentration of any one constituent may vary greatly with time and environmental conditions. Minute quantities of many organic substances have pronounced effects on plant growth, and it is highly probable that, under certain conditions, concentrations of these substances become sufficiently high to cause significant effects on plant growth.

The purpose of this paper is to review research
(122), and others $(17,19,38,48,142,143,144)$ have shown that many actinomycetes and fungi can produce detectable quantities of antibiotics in sterile soils supplemented with organic matter. Grossbard (48) also found that antibiotics were produced in autoclaved soils enriched with readily available sources of carbon and inoculated with Penicillium patulum or Aspergillus clavatus. Hessayon $(52,53)$ and Schmidt (110), in reviews of the literature, cited several reports of toxicity of soil extracts to fungi and bacteria. Antibiotic production in sterile soil was also reported.

TABLE 1. Diameter of fungal colonies with and without alcohol extracts of surface soils ${ }^{a}$

\begin{tabular}{|c|c|c|c|c|c|c|}
\hline \multirow{3}{*}{ Fungus } & \multicolumn{6}{|c|}{ Avg diam of colony ${ }^{b}$} \\
\hline & \multicolumn{2}{|c|}{ Expt A } & \multicolumn{2}{|c|}{ Expt B } & \multicolumn{2}{|c|}{ Expt C } \\
\hline & Control & $\begin{array}{l}\text { Extract from } \\
1 \mathrm{~g} \text { of } \mathrm{P} 55-1\end{array}$ & Control & $\begin{array}{l}\text { Extract from } \\
3 \mathrm{~g} \text { of } P 55-1\end{array}$ & Control & $\begin{array}{l}\text { Extract from } \\
3 \mathbf{g} \text { of } P 54-1\end{array}$ \\
\hline & $m m$ & $m m$ & $m m$ & $m m$ & $m m$ & $m m$ \\
\hline Penicillium humicola. & 21.0 & $19.0^{* *}$ & 23.5 & $19.8^{* *}$ & 23.2 & $19.7^{* *}$ \\
\hline Aspergillus sydowi... & 10.7 & $9.2^{*}$ & 13.7 & $10.8^{*}$ & 12.8 & $10.7^{*}$ \\
\hline Zygorhynchus vuilleminii. & 78.5 & 78.7 & $56.3^{c}$ & $48.5^{* * c}$ & $53.0^{c}$ & $55.5^{c}$ \\
\hline Sporotrichum pruninosum & 20.2 & $18.7^{* *}$ & 24.3 & $20.7^{* *}$ & 22.0 & $19.5^{* *}$ \\
\hline Monilia humicola... & 22.0 & $19.0^{* *}$ & 27.8 & $18.8^{* *}$ & 28.0 & $22.5^{* *}$ \\
\hline
\end{tabular}

a This table appeared first in Soil Sci. 55:377-391, 1943. See reference 90. Published with permission of The Williams \& Wilkins Co.

${ }^{b}$ Average of three plates after 5 days of incubation. Symbols: ${ }^{*}=$ significant by $t$ test in comparison with control, beyond $5 \%$ level; ${ }^{* *}=$ highly significant by $t$ test in comparison with control, beyond $1 \%$ level.

$c$ Diameter measured on third day of incubation.

on microbial decomposition products and organic substances in crop residues and soil which may inhibit plant growth. No attempt was made to review all the literature available. Only typical references are cited to illustrate salient points.

\section{Soil Microbial Products Inhibitory to Microbial Growth}

Numerous investigators $(17,44,48,69,125$, 130) have shown that microorganisms produce a wide variety of compounds (antibiotics) inhibitory to microbial growth. Some of these compounds are toxic to plant growth, as will be discussed later. Many of the compounds are selective in their action; others, such as penicillin, inhibit the growth of a wide variety of microorganisms.

Stevenson (127), Gottlieb et al. (45), Stallings
Newman and Norman (90) showed that dried ethanol extracts of surface soil samples from Marshall silt loam and Clarion silt loam in Iowa contained toxic substances, probably of microbial origin, that inhibited the growth of soil microorganisms as shown in Table 1. The investigators found that aqueous soil extracts did not reduce the growth of soil bacteria. However, the alcoholic extract of both surface and subsurface soil samples reduced the activity of soil microorganisms.

Hessayon (53) found that Trichothecium roseum produced less trichothecin in nonsterile soils than in sterile soils. Clay soils had a higher trichothecin-producing capacity than did sandy ones. Brian $(17,19)$ indicated that a number of fungi, actinomycetes, and bacteria are known to produce antibiotics in both sterile and normal soil if the 
soil is suitably supplemented with organic matter.

Pinck et al. (101, 102) and Soulides et al. (121), in a study of the adsorption of antibiotics by clay minerals, showed that the antibiotics could be classified into three groups: (i) strongly basic (streptomycin, dihydrostreptomycin, neomycin, and kanamycin); (ii) amphoteric (bacitracin, chlortetracycline, and oxytetracycline); and (iii) acidic (penicillin) or neutral (chloramphenicol and cycloheximide). The strongly basic antibiotics with one exception were not released from montmorillonite, vermiculite, or illite. Streptomycin and dihydrostreptomycin were released to varying degrees from kaolinite. The amphoteric antibiotics were released from all the clay minerals. Bioassays indicated that, to be effective in inhibiting microbial growth, the antibiotics had to be released from the clays.

Brian $(17,19)$ showed that, while many antibiotics, such as penicillin, viridin, gliotoxin, frequentin, and albidin, are labile substances and are rapidly decomposed in the soil, others like fradicin and cycloheximide are very stable in a number of soils. Jefferys (56) tested the stability of the antibiotics albidin, frequentin, gladiolic acid, gliotoxin, griseofulvin, mycophenolic acid, patulin, viridin, penicillin, and streptomycin in various soils. The antibiotics persisted in natural soils for varying lengths of time from a few days to more than 20 days, depending on the kind of soil, $\mathrm{pH}$, and microbial activity. Inactivation of the antibiotics was caused by adsorption by soil, microbial activity, or instability of antibiotic at certain $\mathrm{pH}$ levels in the soil. The effect of $\mathrm{pH}$ was important in the inactivation of albidin, frequentin, gliotoxin, penicillin, and viridin. Streptomycin was inactivated largely by adsorption. Biological inactivation of griseofulvin, mycophenolic acid, and patulin was noted.

Many factors appear to be involved in the production as well as the persistence of antibiotics in nonsterile soil. A microorganism that grows well and produces abundant yields of antibiotic in sterile culture may not be able to survive, much less to produce an antibiotic, in competition with the entrenched flora in a nonsterile soil (57). However, Brian (19) states that in certain circumstances antibiotics are produced in appreciable quantities by microorganisms in soil. The chief nutrient requirement for antibiotic production appears to be a suitable carbon source. Thus, sub- stantial amounts of antibiotics were produced in inoculated sterile soil supplemented with organic matter, less in inoculated sterile unsupplemented soil, and little or none in normal soil unless supplemented with large amounts of organic matter. In a normal soil there may be local areas where concentrations of organic matter are sufficiently high to favor the production of antibiotics if the proper microorganisms are present.

\section{Phytotoxic Substances in Plants}

Many plants contain substances that adversely affect seed germination and plant growth $(39,79$, 140). The return to the soil of residues from such plants provides an obvious source of phytotoxic materials whose formation does not depend upon the activity of microorganisms.

\section{Germination Inhibitors}

Cox et al. (29) found germination inhibitors in the seed coat of certain varieties of cabbage. The inhibitor could be removed with water, alcohol, or sulfuric acid. Smith (120) showed that chaff of small grains inhibited the germination of cereals. Siegel (117) found that water extracts of red kidney beans inhibited germination and growth of flax and wheat. Various experiments with the extracted material indicated that more than one inhibitor was present. Barton and Solt (7) demonstrated germination inhibitors of wheat seeds in extracts of seeds of Sorbus aucuparia, Berberis thunbergii, of three varieties of Lactuca, and of nondormant seeds of Phaseolus sp., Triticum sp., Hordeum sp., Glycine sp., Solanum melongena, and Nicotiana tabacum.

Evenari (39), in a review article, reported that germination inhibitors are widely distributed in many plant species. Thus, inhibitors were found in the pulp, juice, and coat of fruit, in seed coat and embryo, in the leaf sap, and in bulbs and roots. Some of the materials responsible for germination inhibition were: (i) hydrogen cyanide from amygdalin in many seeds; (ii) ammonia, released by hydrolysis of nitrogenous compounds; (iii) ethylene, liberated from many fruits as well as from whole plants; (iv) mustard oils containing isothiocyanate derivatives; (v) organic acids, such as malic and citric acids formed by the guayule plant, or caffeic and ferulic acids from tomato juice; (vi) unsaturated lactones, such as parasorbic acid, anemonin, and coumarin; (vii) aldehydes, such as benzaldehyde, salicylaldehyde, 
TABLE 2. Effect of aqueous extracts of plants on germination and growth of Mida wheat*

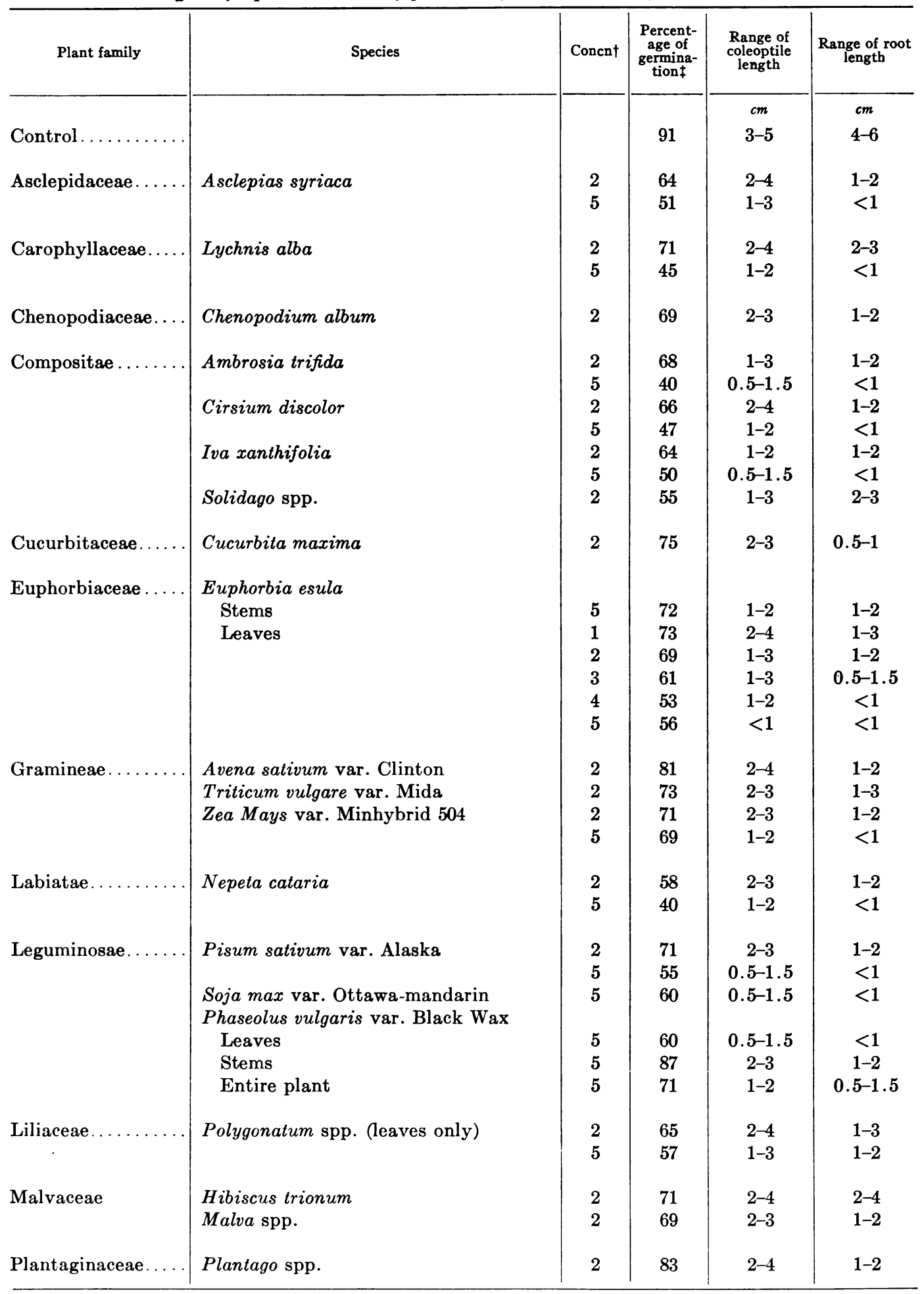


TABLE 2-(cont.)

\begin{tabular}{c|c|c|c|c|c}
\hline \multicolumn{1}{c|}{ Plant family } & Species & Concn $\dagger$ & $\begin{array}{c}\text { Percent- } \\
\text { age of } \\
\text { germina- } \\
\text { tionf }\end{array}$ & $\begin{array}{c}\text { Range of } \\
\text { coleoptile } \\
\text { length }\end{array}$ & $\begin{array}{c}\text { Range of root } \\
\text { length }\end{array}$ \\
\hline & Polygonum pennsylvanicum & & $\mathrm{cm}$ & $\mathrm{cm}$ \\
Polygonaceae...... & Poly & 2 & 76 & $2-3$ & $1-2$ \\
Portulacaceae...... & Portulaca oleracea & 2 & 75 & $2-3$ & $<1$ \\
Solanaceae......... & Lycopersicon esculentum var. Marglobe & 2 & 58 & $1-3$ & $0.5-1.5$ \\
Umbelliferae....... & Petroselenium hortense & 3 & 68 & $2-4$ & $1-3$ \\
\hline
\end{tabular}

* This table appeared first in Weeds 4:363-368, 1956. See reference 68 .

$\dagger$ Concentration listed is equal to number of grams of dry plant material extracted with $100 \mathrm{ml}$ of water.

$\ddagger$ Germination period was 4 days.

and cinnamaldehyde; (viii) essential oils containing a wide variety of aromatic and alicyclic compounds; and (ix) alkaloids, such as cocain, physostigmin, caffein, chinin, berberin, and codein.

In general, substances considered to be germination inhibitors were found to have stimulatory effects on germination at suitable concentrations. The inhibitors are presumably operative through their effects on enzyme activity and other physiological activities of the plant.

\section{Growth Inhibitors}

Borner (14) indicated that many plants contain plant growth inhibitors. Plants such as bromegrass, sweetclover, guayule, and walnut may contain or excrete into the soil materials that are inhibitory to the growth of other plants as shown by Bonner (12), Bonner and Galston (13), and Woods (140).

Plants containing growth inhibitors. Breazeale (16) in 1924 noted the adverse effects of sorghum on succeeding crops. In 1941, Benedict (9) observed a significant reduction in top growth of bromegrass grown in sand culture with various amounts of dead bromegrass roots. He concluded that lack of nitrogen was not the cause for the reduced growth, as was suggested later by Myers and Anderson (88), inasmuch as the treatments containing roots were richer in nitrate nitrogen than were the untreated controls. Pure stands of bromegrass often become sod-bound, a condition which results in reduced top growth and a thinning of the stand. Sod-binding has been attributed to dense root growth and to a lack of available nitrogen. However, on the basis of Benedict's work (9), it is reasonable to expect that some growth-inhibiting factor present in bromegrass roots may be involved in sod-binding.

Bennett and Bonner (10) made a survey of shrubs native to the Mojave Desert for the occurrence of plant growth inhibitors. Relatively toxic extracts were obtained from Sarcobatus virmiculatus, Prosopis juliflora, and Viguiera reticulata. The extract of Thamnosma montana Torr. and Frem. was the most toxic to the extracts tested, with tomato as the assay plant. Two highly toxic crystalline compounds were isolated from this extract and were assigned the empirical formulas $\mathrm{C}_{16} \mathrm{H}_{15} \mathrm{O}_{6}\left(\mathrm{OCH}_{3}\right)$ and $\mathrm{C}_{11} \mathrm{H}_{4} \mathrm{O}_{3}$ $\left(\mathrm{OCH}_{3}\right)_{2}$. Ultraviolet-absorption spectra of the compounds indicated that they were similar in structure.

LeTourneau et al. (68) found that aqueous extracts of dried plant material representing 24 different species contained inhibitors of wheat germination and growth (Table 2). Autoclaving the aqueous extracts did not destroy their inhibitory activity.

Nielsen et al. (92) determined the effect of water extracts of five crop residues (alfalfa, corn, oats, potatoes, and timothy) on the germination and growth of six plant species: alfalfa, corn, oats, peas, soybeans, and timothy. In general, alfalfa extract caused the greatest reduction in shoot and root length as well as percentage germination. Plant species differed greatly in tolerance to the extracts, alfalfa being the most tolerant and timothy the least. 
LeFevre and Clagett (67) found that water extracts of quackgrass rhizomes inhibited growth of eight crop plants by 50 to $84 \%$. Upon concentration by paper chromatography and ion-exchange column techniques, the growth inhibitor was found to be anionic, soluble in polar solvents, insoluble in nonpolar solvents, and unstable in strong acids and bases.

Jameson (55) prepared water extracts and 50 and $100 \%$ ethyl alcohol extracts of leaves and herbaceous stems of plants representing 20 different species, including nine trees and shrubs, eight forbs and half shrubs, and three grasses. Extracts of all species tested inhibited the growth of wheat radicles. Extracts of Cordylanthus wrightii had the greatest inhibitory effect; those of Erodium cicutarium and Agropyron smithii had the least effect. Although the greatest inhibitory effects were noted in extracts of species that also displayed the strongest toxic effects in the field, Jameson concluded that the existence of a growth inhibitor in a plant extract does not necessarily mean that the inhibitor is of ecological importance in the field.

Guenzi and McCalla (49) made water extracts of sweetclover stems, wheat straw, soybean hay, bromegrass hay, oat straw, sweetclover hay, and corn and sorghum stalks, and observed their effects on growth of sorghum, corn, and wheat seedlings. The toxicity of the extracts increased in the order of their listing.

Cochrane (25) found that corn residue increased root rot and decreased yield of lettuce. The residue, added to soil in concentrations of 0 , 1,2 , and $5 \%$, caused lettuce seedling mortalities of $0,0,41$, and $44 \%$, respectively. After the soilresidue mixture was incubated under warm, moist conditions for a period of 30 days, seedling mortalities were reduced to $8,3,0$, and $5 \%$, respectively. The effect was not attributable to nutrient starvation nor to simple pathogenesis by a nematode or microorganism. Cochrane suggested that the plant residues exerted a direct toxic effect on the roots of susceptible plants, which was probably complicated by action of secondary rotproducing microorganisms.

Other growth inhibitors have been reported in leaves and stems of sugarcane (35), immature soybean seeds (61), guayule roots (13), oxalis roots (12), in macadamia (Macadamia integrifolia, M. tetraphylla, and their hybrids) (86), and in chou moellier (Brassica oleraceae var.) (23). Obviously, growth-inhibiting substances are widely distributed among plant species.

Nature of growth inhibitors in plants. Borner (14), in a review dealing with liberation of organic substances from higher plants in relation to soil sickness, discussed the following compounds: (i) liberated from roots-amino acids, sugars, scopoletin and scopoletin glycoside, trans-cinnamic acid, and enzymes; (ii) liberated from seeds and fruits-amino acids, sugars, flavones, phenolic compounds, and gaseous excretions (ethylene, ammonia, hydrocyanic acid); (iii) liberated from plant residues-phenolic compounds, 3acetyl-6-methoxybenzaldehyde, amino acids, amygdalin, coumarin, and phlorizin; (iv) liberated from leaves - absinthin, amino acids, and juglone.

Woods (140), in a review of biological antagonism due to phytotoxic root exudates, indicated that representatives of many plant families produce phytotoxic root exudates containing oils, antibiotics, coumarin, alkaloids, thiamin, biotin, mineral salts, enzymes, aldehydes, nitrogenous compounds, ammonia, amino acids, nucleotides, and nucleic acid derivatives.

Garb (43) listed additional plant constituents with growth-inhibiting properties as follows: protoanemonin from Anemone pulsatilla; byakangelicin from Thamnosma montana; parasorbic acid from Sorbus aucuparius; vanillin from vanilla bean; arbutin from Bergenia crassifolia and Pyrus communis; scopoletin from oats (Avena); and umbelliferone, plant not listed.

In other work on the production of growth inhibitors by plants, Bonner (12) found that oxalic acid was secreted by the roots of oxalis; Bonner and Galston (13) observed that trans-cinnamic acid was secreted by guayule roots; and Gray and Bonner (46, 47) identified 3-acetyl-6-methoxybenzaldehyde in extracts of Encelia farinosa leaves.

\section{Early Work on Phytotoxic Substances Found in Plant Residues and Soll}

As indicated in the introduction, Liebig's work in the nineteenth century was followed by a period during which relatively little emphasis was given to studies dealing with the role of organic matter in plant nutrition. However, sporadic efforts have been made to demonstrate the importance of organic matter for plant growth. Several examples of such work, done between 1900 
and 1925, have been selected for inclusion in this review.

\section{Isolation of Specific Compounds from Soil}

About 1910, Schreiner and Shorey (113) and others $(111,112,118)$, in attempting to explain the poor growth of plants on some soils, isolated specific organic compounds from the soil. One of the compounds was dihydroxystearic acid, a substance which reduced plant size and had the additional effects of darkening the root tips, stunting root development, causing enlarged root ends which were often turned upward like fishhooks, and strongly inhibiting the oxidizing power of the roots. When this compound was added to nutrient solutions, it was toxic to plant growth in concentrations of about 20 to $100 \mathrm{ppm}$ (Table 3). However, the effect of dihydroxystearic acid was

TABLE 3. Effect of dihydroxystearic acid on growth and transpiration of wheat seedlings in solution culture*

\begin{tabular}{ccc}
\hline \multirow{2}{*}{$\begin{array}{c}\text { Concn of dihydroxystearic } \\
\text { acid }\end{array}$} & \multicolumn{2}{c}{ Percentage of control } \\
\cline { 2 - 3 } & Transpiration & Green wt \\
\hline$p p m$ & & \\
20 & 75 & 87 \\
50 & 56 & 78 \\
100 & 24 & 53 \\
200 & 20 & 54
\end{tabular}

* This table appeared first in U.S. Dept. Agr. Bur. Soils Bull. 53:1-53, 1909. See reference 113.

largely neutralized in soil. Fraps (41) found that vanillin and coumarin were oxidized rapidly in the soil; about 20 to $50 \%$ disappeared within 2 weeks.

Schreiner and Skinner (114), Fraps (41), and Funchess (42) showed that the harmful effect of dihydroxystearic acid could be largely overcome by adequate mineral fertilization of the plant. However, toxic effects of coumarin and vanillin were not prevented by the application of inorganic nutrients.

Skinner and Noll (119) found vanillin and salicylic aldehyde in a silty clay loam soil at Arlington Farms, Va., several months after these compounds were applied and after the end of the crop season. On plots fertilized with sodium nitrate, however, vanillin was quickly destroyed. Neither vanillin nor salicylic aldehyde persisted in limed soil. Truog and Sykora (135) found that finely divided soil materials such as lime, soil, kaolin, or quartz largely neutralized the phytotoxicity of vanillin or guanidine carbonate.

\section{Effect of Straw on Plant Growth}

On the basis of qualitative chemical tests, Collison and Conn (27) concluded that salicylic acid, dihydroxystearic acid, and vanillin were present in straw. They suggested that these compounds might account for the detrimental effect of straw on plant growth, although they were also aware of the carbon-nitrogen relationships which had been demonstrated by the classical works of Doryland (34) and Murray (87). Collison (26) observed that water extracts of straw and alfalfa hay were toxic to barley seedlings. The extract from alfalfa hay was more toxic than that from wheat straw. Autoclaving the water extract did not destroy the toxic factor. Later, Myers and Anderson (88) discounted the toxicity idea and concluded from their experiments that the inhibitory effect resulted simply from the tie-up of available nitrogen by plant residues such as straw.

\section{Recent Work on the Occurrence of Phytotoxic Substances in Soll and the Production of These Sub- STANCES BY Microorganisms}

The discovery of antibiotics in 1929 by Fleming and the discovery of plant hormones or growth substances by Went and others $(3,11,139)$ provided new stimulation for studies concerned with the influence of organic soil constituents on plants.

Organic substances in the soil are produced by or derived from animals, plants, and microorganisms. As Starkey (123) indicated, these organic materials in the rhizosphere may have a variety of effects on plants. For example, plant growth may be stimulated or inhibited, or the food value of the plant may be affected. In this review, primary emphasis is placed on microorganisms as the sources of these organic substances, although plant or animal sources will be discussed, particularly as they serve as substrates for microbial action.

\section{Influence of Certain Organic Compounds and Antibiotics on Plant Growth}

Prill et al. (104) studied the growth of wheat roots in the presence of a large number of organic acids in concentrations ranging from 0.002 to 6.25 
TABLE 4. Lowest concentration of added organic compounds showing toxicity to ladino clover seedlings in a complete nutrient culture, and the concentrations allowing optimal normal growth in the absence of inorganic nitrogen*

\begin{tabular}{|c|c|c|c|c|c|}
\hline Organic compound & $\begin{array}{l}\text { Lowest } \\
\text { toxic concn }\end{array}$ & $\begin{array}{l}\text { Concn for } \\
\text { optimal } \\
\text { growth }\end{array}$ & Organic compound & $\begin{array}{l}\text { Lowest } \\
\text { toxic concn }\end{array}$ & $\begin{array}{l}\text { Concn for } \\
\text { optimal } \\
\text { growth }\end{array}$ \\
\hline & $p p m$ & $p p m$ & & $p p m$ & $p p m$ \\
\hline Amino Acids & & & Vitamins (cont.) & & \\
\hline L-Cystine $\ldots \ldots \ldots \ldots$ & NT & Sl & Pyridoxine-HCl...... & 500 & Un \\
\hline D-Isoleucine. . & NT & 1,000 & $p$-Aminobenzoic acid. & 200 & 200 \\
\hline DL-Lysine. . . . . . . & NT & 500 & Niacinamide.......... & 200 & 200 \\
\hline L-Tyrosine $\ldots \ldots \ldots \ldots \ldots$ & NT & 200 & Nicotinic acid ....... & 200 & Un \\
\hline Cysteine-HCl . & 1,000 & Un & Pyridoxal-HCl........ & 200 & Un \\
\hline Hydroxyproline... & 1,000 & 500 & & & \\
\hline L-Isoleucine $\ldots \ldots \ldots \ldots$ & 1,000 & 1,000 & Antibiotics & & \\
\hline DL-Isoleucine...... & 1,000 & 1,000 & Penicillin G-K.... . & 1,000 & - \\
\hline L-Leucine . . . . . . & 1,000 & 500 & Penicillin G-Na......... & 1,000 & - \\
\hline DL-Serine $\ldots \ldots \ldots \ldots \ldots$ & 1,000 & 500 & Chlortetracycline-HCl ..... & 50 & - \\
\hline Tryptophan........... & 1,000 & 200 & Oxytetracycline ......... & 50 & - \\
\hline DL-Alanine....... & 500 & $200-500$ & Streptomycin......... & 50 & - \\
\hline $\mathrm{D}$-Arginine $\mathrm{HCl}$. & 500 & 50 & Bacitracin ............ & 5 & - \\
\hline L-Asparagine . . . & 500 & 200 & Chloramphenicol.......... & 5 & - \\
\hline L-Aspartic acid... & 500 & 500 & & & \\
\hline D-Glutamic acid.. & 500 & 500 & Miscellaneous & & \\
\hline Glycine............. & 500 & 200 & Fumaric acid ........ & NT & - \\
\hline L-Histidine- $\mathrm{HCl}$. & 500 & 500 & Maleic anhydride... & NT & - \\
\hline L-Proline ......... & 500 & 500 & $\mathrm{Na} \mathrm{Cu}$ chlorophyllin...... & NT & - \\
\hline DL-Threonine $\ldots \ldots \ldots \ldots$ & 500 & 500 & 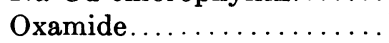 & NT & - \\
\hline DL-Valine . & 500 & 500 & Rutin $\ldots \ldots \ldots \ldots \ldots$ & NT & 一 \\
\hline DL-Methionine . . & 200 & Un & Succinic acid. & NT & - \\
\hline DL-Norleucine . . . . . . . & 200 & Sl & Tannic acid. & NT & - \\
\hline L(+)-Glutamic acid. & - & 200 & Arbutin...... & 1,000 & - \\
\hline & & & Citric acid $\ldots \ldots \ldots \ldots \ldots$ & 1,000 & - \\
\hline Nucleic Acid Group & & & Malic acid ............. & 1,000 & - \\
\hline Nucleic acid ......... & NT & 1,000 & Malonic acid . . . . . . . . & 1,000 & - \\
\hline Adenylic acid. & 1,000 & 1,000 & Methylamine-HCl . . . . . . & 1,000 & 200 \\
\hline Guanine-HCl......... & 500 & 50 & Pancreatin ............ & 1,000 & - \\
\hline Uracil .............. & 500 & 200 & Pepsin $\ldots \ldots \ldots \ldots \ldots$ & 1,000 & - \\
\hline Adenine sulfate... & 200 & 50 & Vanillin .......... & 1,000 & - \\
\hline Xanthine ......... & 200 & Un & Catechol .............. & 500 & - \\
\hline & & & Cinnamic acid . . . . . . . . & 500 & - \\
\hline Alkaloids & & & Creatinine............. & 500 & 50 \\
\hline L-Hyoscyamine.... & NT & Un & Diethylphosphite ........ & 500 & - \\
\hline Atropine........ & NT & Un & Phloroglucinol........... & 500 & - \\
\hline Brucine........ & 500 & Un & $\alpha$-Picoline . . . . . . . . . & 500 & Un \\
\hline Morphine ........ & 500 & Un & Pyridine .............. & 500 & Un \\
\hline Nicotine ....... & 500 & Un & Dimethylhydroresor- & & \\
\hline Trigonelline.... & 500 & $200-500$ & cinol $\ldots \ldots \ldots \ldots$ & 200 & - \\
\hline Arecoline ...... & 200 & Un & $\mathrm{Na}$ taurocholate........... & 200 & Un \\
\hline Caffeine ............ & 50 & Un & Succinimide $\ldots \ldots \ldots \ldots \ldots$ & 200 & 50 \\
\hline Quinidine .......... & 50 & Un & Aniline nitrate .......... & 50 & Un \\
\hline Nicotyrine...... & 50 & Un & Barbital. . . . . . . . . . . & 50 & Un \\
\hline Nornicotyrine.. & 50 & Un & Biuret................. & 50 & Un \\
\hline Quinine-HCl . . & 50 & Un & Coumarin . . . . . . . . . . & 50 & Un \\
\hline Theobromine... & 50 & Un & Hydroxyquinone.... & 50 & - \\
\hline & & & $m$-Nitrobenzoic acid . ...... & 50 & Un \\
\hline Vitamins & & & Quinone............... & 50 & - \\
\hline Ca panthothenate. & NT & Un & Benzidine . . . . . . . . . & $\mathbf{5}$ & Un \\
\hline Pyridoxamine..... & - & Un & Quinoline............... & 5 & Un \\
\hline Ascorbic acid.... & 1,000 & - & Stovaine .............. & 5 & - \\
\hline Thiamine ........ & 1,000 & Un & Sulf apyridine............ & 5 & Un \\
\hline
\end{tabular}

* This table appeared first in Agron. J. 52:317-319, 1960. See reference 108. NT = not toxic at 1,000 ppm; Un = nitrogen unavailable; $\mathrm{Sl}=$ nitrogen slightly available; - = not tested or non-nitrogenous. 
mM. At the $0.01 \mathrm{~mm}$ concentration, the following aromatic acids were found to be approximately as inhibitory as coumarin: melilotic, phenylpropiolic, hydrocinnamic, piperic, tetrahydropiperic, salicylic, and 2-furanacrylic. At the same concentration, trans-cinnamic, benzoic, and anthranilic acids were less inhibitory than was coumarin. In the fatty acid series, formic, propionic, butyric, caproic, capric, and crotonic acids were more inhibitory than acetic acid at the $0.25 \mathrm{~mm}$ level. Succinic, fumaric, L-malic, and citric acids showed relatively little toxicity.

Audus and Quastel (4) tested the effect of a number of amino acids and amines on the growth of cress roots. Glutamic acid had no toxic effect. Tryptophan and nicotinic acid were definitely toxic at a concentration of $10 \mathrm{ppm}$ in aqueous solution. A number of amino acids and amines were toxic to plant growth at a concentration of $100 \mathrm{ppm}$. Riker and Gutsche (107) also found that a number of amino acids inhibited the growth of sunflower tissue.

Routley and Sullivan (108) investigated a large number of organic substances for possible toxicity to ladino clover seedlings grown in sand culture for 30 days (Table 4). In general, amino acids and compounds related to nucleic acids were of low toxicity, and most of them were able to supply nitrogen to the seedlings. Several alkaloids, antibiotics other than penicillin, and several of the compounds included in the miscellaneous group were highly toxic.

Norman (93) showed that elongation of cucumber roots was inhibited by antibiotics. The following antibiotics, in concentrations of 0.2 to 8.5 $\mu \mathrm{g} / \mathrm{ml}$, produced $50 \%$ inhibition of root elongation: L-cycloserine, azaserine, sulfocidin, magnamycin, oligomycin, oxytetracycline, and D-cycloserine. For gramicidin, tyrothricin, thiolutin, and duramycin, concentrations of 14 to $39 \mu \mathrm{g} / \mathrm{ml}$ were required, and for novobiocin, bacitracin, and vancomycin, concentrations of 140 to $510 \mu \mathrm{g} / \mathrm{ml}$ were needed to produce $50 \%$ inhibition in root elongation.

Brian (18), in a review of the effects of 38 antibiotics on plant growth, stated that most of the antibiotics tested exhibited some degree of phytotoxicity. Four of the antibiotics-cycloheximide azaserine, alternaric acid, and polymyxin-inhibited seed germination and root growth at concentrations of $5 \mu \mathrm{g} / \mathrm{ml}$ or less. One of the least toxic antibiotics was penicillin. Antibiotics may inhibit germination, root growth, shoot growth, and production by plants of foliage, pigment, and plastid.

Barton and MacNab (6) determined the effects of polymyxin, potassium penicillin $G$, streptomycin trihydrochloride, oxytetracycline hydrochloride, and thiolutin on growth of wheat roots. The antibiotics were added to roots growing in distilled water, tap water, and nutrient solution. In concentrations of 1 to 0.1 units per ml, most of the antibiotics stimulated growth, but, in higher concentrations of 1 to 32 units per ml, most of the antibiotics showed toxic properties.

Wright (141) tested the effects of a large number of antibiotics on germination and root growth of wheat, white mustard, and red clover. The least toxic antibiotics were griseofulvin, penicillin, and streptomycin. The more toxic ones were alternaric acid, glutinasin, mycophenolic acid, and gliotoxin. The range of effective concentration of antibiotics was 1 to $25 \mathrm{ppm}$. In most cases, little or no effect on germination was noted. However, antibiotic concentrations that severely inhibited root growth generally also reduced germination percentage. None of the antibiotics was as toxic as indolylacetic acid, but most were more toxic than coumarin. High concentrations $(3,000 \mathrm{ppm})$ of streptomycin retarded chlorophyll formation and cotyledons were completely yellow. Alternaric acid at a concentration of $1 \mathrm{ppm}$ inhibited chlorophyll synthesis in mustard seedlings. Wheat was less susceptible to the antibiotics than was clover or mustard.

If conditions of light, temperature, and moisture are favorable and if mineral nutrients are available in sufficient quantities, plants of many species can grow very well in the absence of added organic compounds. However, if these plants are grown in the presence of vitamins, amino acids, antibiotics, alkaloids, or many other organic compounds, the organic substances may be absorbed and may influence plant growth, as indicated by Krasil'nikov $(65,66)$ and others $(2,21,28,91)$.

\section{Organic Acids and Amino Acids in Soil}

Since many organic and amino acids influence plant growth, it is interesting to know whether these compounds occur naturally in soil. Schwartz et al. (115), in a study of Ohio soils, found that significant amounts of acetic and formic acids and small quantities of other acids, including crotonic and lactic, could be separated from the 
soil. These compounds were probably derived from a group of fatty acids of high molecular weight.

Putnam and Schmidt (106) reported small but detectable amounts of free amino acid in the soil. Soil amended with glucose and inorganic nitrogen yielded a wider variety and greater quantities of free amino acids than did untreated soil. However, under usual soil conditions it is unlikely that

TABLE 5. Amino acids in acid hydrolysates of a Hoytville (Ohio) soil*

\begin{tabular}{|c|c|c|c|}
\hline Amino acid & $\begin{array}{c}\text { Amt (mg/ } \\
100 \mathrm{~g} \text { of } \\
\text { soil) }\end{array}$ & Amino acid & $\begin{array}{c}\text { Amt (mg/ } \\
100 \mathrm{~g} \text { of } \\
\text { soil) }\end{array}$ \\
\hline $\begin{array}{c}\text { Cysteic acid .... } \\
N \text {-acetyl gluco- } \\
\text { samine........ }\end{array}$ & 11 & $\begin{array}{l}\alpha \text {-Amino- } n- \\
\text { butyric } \\
\text { acid...... }\end{array}$ & $\mathbf{P}$ \\
\hline Glucosamine.... & + & Valine....... & 81 \\
\hline Galactosamine... & $\mathbf{P}$ & Methionine & \\
\hline Aspartic acid & 182 & sulfoxide. . & 6 \\
\hline Serine ....... & 182 & Proline...... & 48 \\
\hline Threonine. & 80 & Methionine. . & - \\
\hline Glutamic acid.... & 137 & Isoleucine . . . & 33 \\
\hline Methionine sul- & & Leucine...... & 58 \\
\hline fone . . . . . . . & 10 & Ornithine.... & 35 \\
\hline Hydroxyproline. . & 33 & Cystine ..... & - \\
\hline Glycine..... & 80 & Lysine . . . . . & 69 \\
\hline Alanine.......... & 109 & Histidine.... & 13 \\
\hline$\beta$-Alanine ....... & 10 & Tyrosine.... & 17 \\
\hline $\begin{array}{r}\boldsymbol{\gamma} \text {-Aminobutyric } \\
\text { acid } \ldots \ldots \ldots \ldots\end{array}$ & 2 & $\begin{array}{l}\text { Arginine .... } \\
\text { Phenylal- }\end{array}$ & 12 \\
\hline $\begin{array}{l}\alpha, \epsilon \text {-Diaminopi- } \\
\text { melic acid.... }\end{array}$ & $P$ & anine... & 34 \\
\hline
\end{tabular}

* This table appeared first in Ohio Agr. Expt. Sta. Circ. 61:1-18, 1958. See reference 145. Symbols: $\mathrm{P}=$ provisional identification; $+=$ constituent identified but quantity not estimated; $-=$ not detected.

free amino acid concentrations will become sufficiently high to be toxic to plant growth.

A number of workers [Young and Mortensen (145); Stevenson (127); Paul and Schmidt (98); Payne et al. (99); and others] have isolated amino acids from the soil. The kinds and amounts of amino acids found in an Ohio soil, as determined by chromatographic methods, are shown in Table 5. Stevenson (127) found 29 ninhydrinpositive compounds in Illinois soils.

In view of the widely followed procedures of using strong acids and bases or other strong chemicals as extracting agents, the question might be raised whether significant amounts of free organic or amino acids exist in the soil or whether these compounds are produced as a result of the extraction procedures used.

\section{Influence of Carbon Dioxide, Bicarbonates, Nitrite,} Hydrogen Sulfide, and Ammonia on Plant Growth

In the decomposition of plant and animal residues in the soil, microorganisms produce large quantities of carbon dioxide. Stolwijk and Thimann (129) showed that root growth of Pisum sativum, Vicia faba, Phaseolus vulgaris, and Helianthus annuus was completely inhibited if the root medium was aerated with air containing 6.5\% carbon dioxide. Avena sativa and Hordeum vulgare roots were inhibited only slightly by this

TABLE 6. Carbon dioxide and oxygen concentrations at 6-in. depth of soils sampled at Cornell University, 1940*

\begin{tabular}{|c|c|c|c|c|}
\hline \multirow{2}{*}{ Datef } & \multicolumn{2}{|c|}{$\begin{array}{l}\text { Light silty clay loam } \\
\text { (under light sod) }\end{array}$} & \multicolumn{2}{|c|}{$\begin{array}{l}\text { Silty clay (under } \\
\text { manure mulch) }\end{array}$} \\
\hline & $\mathrm{CO}_{2}$ & $\mathrm{O}_{2}$ & $\mathrm{CO}_{2}$ & $\mathrm{O}_{2}$ \\
\hline & $\%$ & $\%$ & $\%$ & $\%$ \\
\hline 12 July. & 3.5 & 17.2 & 6.1 & 11.6 \\
\hline 15 July. & 3.9 & 16.4 & 5.1 & 13.6 \\
\hline 22 July. & 2.4 & 18.3 & 4.1 & 16.4 \\
\hline 5 August. & 1.0 & 19.8 & 2.8 & 18.7 \\
\hline
\end{tabular}

* This table first appeared in Cornell Univ. Agr. Expt. Sta. Bull. 763:1-43, 1941. See reference 15.

$\dagger$ Soil was wet at beginning of sampling period and began to dry toward the end of the period.

treatment. Root growth of peas was slightly but consistently stimulated in a root atmosphere containing $0.5 \%$ carbon dioxide and was inhibited at a carbon dioxide concentration of $1.5 \%$.

Chang and Loomis (24) found that water absorption by roots of wheat, corn, and rice plants growing in water culture was reduced 14 to $50 \%$ by bubbling carbon dioxide through the solution. Plant growth was adversely affected by reduced water absorption.

Taylor and Abrahams (134) of Ohio, and Boynton (15) at Cornell University, found carbon dioxide concentrations of 1 to $6 \%$ in the surface 6 in. of soil (Table 6). Waksman and Starkey (137) reported carbon dioxide concentrations ranging from traces in aerobic soils to $20 \%$ in anaerobic soils. Thus, in compacted soil with a high level of energy material and microbial decomposition, 
carbon dioxide concentrations probably approach levels detrimental to plant growth. Bicarbonates appear to be a factor contributing to the development of iron chlorosis (22).

Although nitrites even at a low concentration are toxic to plants, under most soil conditions nitrite accumulation does not reach toxic levels. In Arizona, however, nitrite accumulation apparently causes "crazy top" of cotton. Scott (116) indicates that symptoms of this disorder are nondehiscent anthers and apical branches which have shortened internodes and varying degrees of abnormal leaf size, shape, and arrangement. The condition was recognized in 1919 in the Salt River Valley of Arizona, and it appears to be associated with soils having a high $\mathrm{pH}$ and an accumulation of nitrites. Applications of urea or choline chloride temporarily corrected the effects of "crazy top" on anthers, so that pollen was released and normal reproductive processes were completed.

Koike (63) showed that nitrite accumulation in Hawaiian soils was negligible in acid soil $\mathrm{cH}$ 4.3). However, nitrites may accumulate under some conditions, e.g., in alkaline soils and high ammonium levels (1). In a neutral soil ( $\mathrm{pH} \mathrm{6.8)}$ nitrite nitrogen accumulation exceeded $300 \mathrm{ppm}$ within 4 weeks after the application of 1,500 $\mathrm{ppm}$ of nitrogen in the form of $\mathrm{NH}_{4} \mathrm{OH}$. On the other hand, in an alkaline soil ( $\mathrm{pH} 8.0$ ), $300 \mathrm{ppm}$ of nitrite nitrogen accumculated in 1 week from $500 \mathrm{ppm}$ of $\mathrm{N}$ added as $\left(\mathrm{NH}_{4}\right)_{2} \mathrm{SO}_{4}$ and $\mathrm{NH}_{4} \mathrm{OH}$, and oxidation to nitrates was complete in 4 weeks.

In water-saturated soils (e.g., under conditions of prolonged flooding) or in excessively compacted soils, anaerobic decomposition of sulfates or proteins may result in the formation of hydrogen sulfide which, even in low concentrations, is toxic to plants. Neilson-Jones (89) noted the presence of hydrogen sulfide-producing bacteria in a heath soil at Wareham Forest, and concluded that hydrogen sulfide was responsible for the difficulty encountered in growing trees. Alexander (1) indicated that many bacteria, fungi, and actinomycetes can convert sulfates and partially reduced sulfur compounds to sulfides.

Free ammonia is a cell toxin and, therefore, toxic effects on plants would be expected to result if gaseous ammonia concentration became sufficiently high in the soil. In solution culture of plants, toxic effects of ammonia may be found, but it is doubtful that the level of free ammonia in most soils is sufficiently high to cause toxicity.

\section{Production of Phytotoxins by Soil Microorganisms and Plant Pathogens}

Soil microorganisms produce a tremendous variety of organic substances during the decomposition of plant and animal residues, and, as numerous studies have shown, some of these substances are phytotoxic. For example, Swaby (132) found that, when soil microorganisms were present in association with plant residues (lucerne and Phalaris tuberosa), substances inhibitory to plant growth were frequently produced. Hata (50) studied the influence of culture filtrates from 3,300 isolates of soil microorganisms on the growth of Chlorella. He found that 81 isolates (2.5\% of the total) produced growth-accelerating filtrates, 567 (17.2\%) produced growth-inhibiting filtrates, and filtrates from $2,652(80.4 \%)$ had no effect. Curtis (30), on the other hand, found that none of the culture filtrates from 500 actinomycetes was inhibitory to plant growth. Krasil'nikov (66), in a study using 1,500 cultures of actinomycetes, indicated that 5 to $15 \%$ produced substances inhibitory to plant growth.

Krasil'nikov (66) investigated more than 300 cultures of nonsporeforming bacteria for the production of plant growth inhibitors. About 100 of the cultures suppressed plant growth and germination to some degree. Products from certain strains of Pseudomonas fluorescens, $P$. pyocyanea, and Bacterium sp. possessed strong herbicidal properties. More than 560 cultures of sporeforming bacteria were tested for their ability to inhibit germination and plant growth. Of these cultures, 176 strongly suppressed the germination of clover seeds and more than 200 suppressed the germination of peas. Approximately 20 to $30 \%$ of the sporeforming cultures possessed growth-inhibiting properties. Four species, Bacillus mesentericus, B. subtilis, $B$. cereus, and $B$. brevis, accounted for most of the inhibitory spore formers. Among bacteria isolated from turfy podzol soils, 34 to $45 \%$ of the isolates produced plant growth inhibitors.

Krasil'nikov also observed that some strains of actinomycetes caused chlorosis of plants such as corn and that fungi of the genus Fusarium caused chlorosis of grapevines (66). In other studies, Hodgson et al. (54) found that filtrates from crown gall bacteria produced wilting in tomatoes.

$$
\text { At Lincoln, Neb., McCalla et al. (83) found }
$$


that, of 91 fungi isolated from stubble-mulched plots where plant growth was reduced, 14 produced culture filtrates that reduced by $50 \%$ or more the germination of corn seeds soaked therein. In another test, corn seedlings were grown on filter paper soaked in the autoclaved culture filtrates from fungi isolated at random from platings of soil representing stubble-mulched plots at Lincoln, Neb. Of 318 filtrates tested, 52 reduced shoot growth by $50 \%$ or more, and 167 reduced root growth by a comparable percentage.

Gibberella fujikuroi. Stowe and Yamaki (131) and Stowe et al. (130) discussed the history of the gibberellins and the relationship of these compounds to the bakanae (foolish seedling) effect, a serious disease of rice. According to these authors, the Japanese plant pathologist, Sawada, in 1912 suggested that a fungus might be the cause of the bakanae effect. More recently, it has been established that this disease is caused by $G$. fujikuroi (San.) ver., and that this fungus produces gibberellins which stimulate stem elongation in the rice plant, resulting in the tall growth that is characteristic of the diseased plants $(130$, 131). Severe infection with this fungus leads to adventitious root formation at the aerial nodes, stem curvature at the nodes, leaf curl, root rot, and death of the plants before flowering. Temperature is an important factor in the bakanae effect on rice. The optimal temperature for growth of the organism is $27 \mathrm{C}$, infection occurs best at $30 \mathrm{C}$, and the bakanae effect is most pronounced at $35 \mathrm{C}$.

Brian et al. (20) indicated that wheat grown in weak nutrient solution and treated with gibberellic acid became chlorotic. This chlorosis could be largely overcome by increasing the concentration of the nutrient solution. Morgan and Mees (85) reported similar results with pasture grass. In this case, the chlorosis could be overcome by the addition of nitrogen fertilizer with the gibberellic acid. Although gibberellins can induce stem elongation, very high concentrations of these substances are inhibitory to growth. "Overgrowth" in plants other than rice does not seem to occur naturally, but artificial infection with the bakanae organism leads to overgrowth in corn, millet, wheat, and oats (70, 131).

Stowe et al. (130) found that G. fujikuroi also produced a growth-deterring substance, fusaric acid, (5-n-butyl picolinic acid), which they ex- tracted from culture solutions with benzene or petroleum ether. They suggested that growth retardation sometimes observed in rice infected with bakanae organisms was due to fusaric acid. This compound, now a patented plant growth inhibitor and wilting agent, is effective in concentrations as low as $0.1 \mathrm{mg}$ per liter. Its effect seems to depend upon its chelating properties-it is a strong inhibitor of heme-containing enzymes. Its activity may be partially reversed by the addition of minor elements.

Penicillium. A number of species of the genus Penicillium produce substances toxic to plant growth. Mirchink (84), in a study of soil toxicity at the Agrobiological Station in Chashnikov (Moscow area, Khimkin sector), isolated a number of fungi, including numerous representa-

TABLE 7. Number of toxic fungal forms in different experimental variants*

\begin{tabular}{|c|c|c|c|}
\hline Experimental variants & $\begin{array}{l}\text { No. of } \\
\text { isolated } \\
\text { strains }\end{array}$ & No. toxic & $\begin{array}{l}\text { Percentage } \\
\text { of toxic } \\
\text { strains }\end{array}$ \\
\hline $\begin{array}{l}\text { Control (without fer- } \\
\text { tilizer) } \ldots \ldots \ldots \ldots \ldots\end{array}$ & 105 & 34 & 32 \\
\hline Nitrogen. & 172 & 63 & 38 \\
\hline $\begin{array}{l}\text { Lime }+ \text { manure } \ldots \\
\text { Lime }+ \text { manure }+\end{array}$ & 85 & 21 & 24 \\
\hline NPK........... & 68 & 10 & 15 \\
\hline
\end{tabular}

* This table appeared first in Microbiology USSR (Engl. Transl.) 26:83-90, 1957. See reference 84 .

tives of the genus Penicillium, which produced phytotoxic substances, as shown in Tables 7,8 , 9 , and 10. Liming of the soil and the addition of manure reduced the percentage of toxic forms. The most toxic fungi were $P$. cyclopium West., P. nigricans Thom. (Bain.), P. paxilli Bain., and $P$. janthinellum Biour. The phytotoxic materials were formed in the soil upon the addition of small amounts of organic matter and inoculation with an appropriate strain of Penicillium.

Curtis (31) found that, when $P$. thomii Maire culture filtrates were placed on the leaves of bean and corn, the leaves became chlorotic, slightly necrotic, and were smaller than the untreated leaves. Norstadt and McCalla (94), in a study of factors causing reduction of crop yields on stubble-mulched soil, isolated $P$. urticae Bainier from a stubble-mulched plot where plant growth had been poor. When sterile soil was 
TABLE 8. Action of culture fluid from highly toxic forms on wheat seeds*

\begin{tabular}{|c|c|c|c|}
\hline Strain & Species of fungus & $\begin{array}{l}\text { Germi- } \\
\text { nated } \\
\text { seeds (\% } \\
\text { of con- } \\
\text { trol) }\end{array}$ & $\begin{array}{l}\text { Sprout } \\
\text { length in } \\
\mathrm{cm} \text { (avg) }\end{array}$ \\
\hline & $\begin{array}{l}\text { Control (nutrient } \\
\text { medium) }\end{array}$ & 100 & 4.6 \\
\hline & Control (water) & 100 & 4.6 \\
\hline $\mathrm{C} \mathrm{I} / 8$ & $\begin{array}{l}\text { Penicillium cyclo- } \\
\text { pium Weste }\end{array}$ & 0 & - \\
\hline D II $/ 5$ & P. paxilli Bain. & 54 & 2.6 \\
\hline C II $/ 10$ & $\begin{array}{l}P . \text { janthinellum } \\
\text { Biour. }\end{array}$ & 74 & 1.5 \\
\hline $\mathrm{D} \mathrm{II} / 4$ & $\begin{array}{l}P . \text { martensii } \\
\text { Biour. }\end{array}$ & 74 & 3.0 \\
\hline II $/ 14$ & $\begin{array}{l}P . \text { nigricans Thom } \\
\text { (Bain.) }\end{array}$ & 100 & 1.0 \\
\hline II $/ 35$ & $\begin{array}{l}\text { P. nigricans Thom } \\
\text { (Bain.) }\end{array}$ & 87 & 0.6 \\
\hline C VIII/81 & $\begin{array}{l}\text { P. nigricans Thom } \\
\text { (Bain.) }\end{array}$ & 90 & 1.0 \\
\hline C VI/4 & $\begin{array}{l}\text { Trichoderma } \\
\text { koningii }\end{array}$ & 68 & 3.6 \\
\hline D IV $/ 4$ & Fusarium sp. & 68 & 4.5 \\
\hline
\end{tabular}

* This table appeared first in Microbiology USSR (Engl. Transl.) 26:83-90, 1957. See refererence 84 .

TABLE 9. Action of soil containing different concentrations of sucrose and infected with a culture of Penicillium cyclopium on the germination and growth of wheat seeds*

\begin{tabular}{|c|c|c|c|}
\hline Variants & $\begin{array}{l}\text { Sucrose } \\
\text { added }\end{array}$ & $\begin{array}{l}\text { Germinated } \\
\text { seeds (\% of } \\
\text { control) }\end{array}$ & $\begin{array}{l}\text { Length of } \\
\text { sprouts }\end{array}$ \\
\hline & $\%$ & & $\mathrm{~cm}$ \\
\hline $\begin{array}{l}\text { Control (sterilized non- } \\
\text { infected soil) } \ldots \ldots \ldots\end{array}$ & - & 100 & 5.5 \\
\hline P. cyclopium...... & 1 & 5 & 0.5 \\
\hline P. cyclopium... & 0.5 & 20 & 2.0 \\
\hline P. cyclopium. & 0.2 & 40 & 0.2 \\
\hline
\end{tabular}

* This table appeared first in Microbiology USSR (Engl. Transl.) 26:83-90, 1957. See reference 84.

supplemented with sterile plant residues, inoculated with $P$. urticae Bainier, and incubated for 2 weeks, wheat seeds planted in this soil showed reduced growth in comparison with untreated controls (8). The active growth inhibitor was isolated and identified as patulin. Barnum (5) demonstrated that $P$. expansum. Link. produced substances that caused wilting of Malva rotundifolia L., vetch (Vicia gigantea Hook), mint (Mentha sp.), cauliflower (Brassica oleraceae var. Botrytis), and alfalfa (Medicago sativa L.).

Aspergillus. Curtis (32,33) observed curvature of corn roots treated with $A$. niger culture filtrates. Other malformations consisted of greatly thickened stems and petioles, and tumorlike stems. The active substance was isolated and designated as malformin. It is a neutral peptide containing four amino acids, valine, leucine,

TABLE 10. Distribution of highly toxic fungal forms among field plots treated with fertilizers*

\begin{tabular}{|c|c|c|}
\hline $\begin{array}{c}\text { Experimental } \\
\text { variants }\end{array}$ & Species of fungus & $\begin{array}{l}\text { No. of } \\
\text { strains }\end{array}$ \\
\hline Control & $\begin{array}{l}\text { Penicillium } \\
\text { cyclopium Weste } \\
\text { P. nïgricans Thom (Bain.) } \\
P . \text { paxilli Bain. } \\
P . \text { janthinellum Biour. }\end{array}$ & $\begin{array}{r}2 \\
2 \\
5 \\
10\end{array}$ \\
\hline Nitrogen & $\begin{array}{l}P . \text { nigricans Thom (Bain.) } \\
P . \text { janthinellum Biour. } \\
P . \text { paxilli Bain. } \\
P . \text { martensii Biour. }\end{array}$ & $\begin{array}{r}3 \\
20 \\
1 \\
6\end{array}$ \\
\hline$\underset{\text { lime }}{\text { Manure }}+$ & $\begin{array}{l}\text { P. janthinellum Biour. } \\
P . \text { nigricans Thom (Bain.) } \\
P . \text { paxilli Bain. }\end{array}$ & $\begin{array}{l}1 \\
2 \\
1\end{array}$ \\
\hline $\begin{array}{l}\text { Manure }+ \\
\text { lime }+ \\
\text { NPK }\end{array}$ & $\begin{array}{l}P . \text { janthinellum Biour. } \\
P . \text { nigricans Thom (Bain.) } \\
P . \text { paxilli Bain. }\end{array}$ & $\begin{array}{l}1 \\
1 \\
1\end{array}$ \\
\hline
\end{tabular}

* This table appeared first in Microbiology USSR (Engl. Transl.) 26:83-90, 1957. See reference 84.

isoleucine, and one-half cystine. Takahashi and Curtis (133) suggested that malformin is a cyclic peptide with the molecular formula $\mathrm{C}_{23} \mathrm{H}_{39} \mathrm{~N}_{5} \mathrm{O}_{5} \mathrm{~S}_{2}$. The infrared spectrum indicated strong adsorption at 3.01, 6.06, and 6.54 $\mu$. Postlethwait and Curtis (103) found that bean seedlings treated with a culture filtrate of $A$. niger exhibited severe curvature, increased diameter, reduced length, and irregular protrusions of stem and leaf petioles.

Trichoderma and Fusarium. Mirchink (84) found that the culture filtrates of species of the genera Fusarium and Trichoderma were less phytotoxic than were species of the genus Penicillium. Fahmy (40) showed that $F$. solani pro- 
duced a toxic substance capable of causing wilting of plants.

Alternaria. Ryan et al. (109) observed chlorophyll deficiency in citrus seedlings grown from seeds that had been in contact with culture extracts of the $A$. tenuis during germination. The active material also inhibited chlorophyll formation in the seedlings of various other plant species.

Other microorganisms. Phytotoxins are pro- toxic substances were soluble in water and insoluble in petroleum ether; stable to acid, heat, and storage at -3 to $1 \mathrm{C}$; and were precipitated by alkali. The substances were most active in the $\mathrm{pH}$ range of 4.5 to 5.8 , were nonspecific in action on the plants tested, and were antifungal in some instances. The inhibitory materials apparently were much more abundant in a water-saturated soil than in a soil at field capacity (Table 12).

TABLE 11. Effect of plant maturity and period of decomposition on relative toxicity of the resulting products on respiration of 6 -day-old tobacco seedlings*

\begin{tabular}{|c|c|c|c|c|c|c|c|c|}
\hline \multirow{2}{*}{ Age of plant material added to soil } & \multirow{2}{*}{ Type of plant } & \multicolumn{7}{|c|}{ Decomposition period (days) at 60 to $70 \mathrm{~F}$} \\
\hline & & 0 & 5 & 10 & 15 & 20 & 25 & 30 \\
\hline \multirow{5}{*}{$\begin{array}{l}\text { Young ( } 5 \text { to } 6 \text { weeks after } \\
\text { planting) }\end{array}$} & Soil only & $-\dagger$ & - & - & - & - & - & - \\
\hline & Timothy & - & + & ++ & +++ & ++ & - & - \\
\hline & Rye & - & - & + & ++ & + & - & - \\
\hline & Corn & - & - & + & ++ & + & - & - \\
\hline & Tobacco & - & - & + & + & - & - & - \\
\hline \multirow{5}{*}{$\begin{array}{l}\text { Intermediate ( } 6 \text { to } 8 \text { weeks after } \\
\text { planting) }\end{array}$} & Soil only & - & - & - & - & - & - & - \\
\hline & Timothy & - & + & +++ & +++ & ++ & +++ & ++ \\
\hline & Rye & - & + & ++ & +++ & +++ & ++ & ++ \\
\hline & Corn & - & - & ++ & +++ & ++ & +++ & ++ \\
\hline & Tobacco & - & - & + & +++ & ++ & - & - \\
\hline \multirow{5}{*}{$\begin{array}{l}\text { Mature (10 to } 14 \text { weeks after } \\
\text { planting) }\end{array}$} & Soil only & - & - & - & - & - & - & - \\
\hline & Timothy & - & - & - & ++ & ++ & +++ & +++ \\
\hline & Rye & - & - & - & + & ++ & +++ & ++ \\
\hline & Corn & - & - & - & + & ++ & +++ & +++ \\
\hline & Tobacco & - & - & - & + & ++ & ++ & - \\
\hline
\end{tabular}

* This table appeared first in Can. J. Botany 36:621-647, 1958. See reference 96.

$\dagger$ Toxicity rating: $-=$ nontoxic (extracts which inhibit respiration of 6 -day-old tobacco seedlings by less than $19 \%)+,++,+++=$ mild, intermediate, and high toxicity, producing inhibition of respiration of $20-40 \%, 41-60 \%$, and $61-95 \%$, respectively.

duced by a large variety of microorganisms in addition to those listed here. No attempt has been made to present a complete listing of these organisms in this review.

\section{Phytotoxic Substances in Decomposing Plant Residues, Soil Organic Matter, and Soil}

Patrick and Koch (96) observed inhibition of respiration in tobacco seedlings caused by the decomposition of timothy, corn, rye, and tobacco plant residues in soil (Table 11). Germination and growth also were adversely affected by these substances. These toxic materials resulted when crop residues were decomposed for 10 to 30 days in wet soil at $\mathrm{pH}$ levels below 5.5. The highest toxicity was obtained with residues of timothy, followed by corn, rye, and tobacco residues. The
Patrick et al. (97) conducted field studies in the Salinas Valley, Calif., which revealed that injury to roots of lettuce and spinach seedlings was on those parts of the roots in direct contact with decomposing plant residues. Water-soluble substances inhibiting the growth of seedlings were extracted from plant residues decomposing in field soils. Phytotoxicity was most severe after barley, rye, wheat, sudangrass, vetch, broad beam, and broccoli residues had decomposed for 10 to 25 days. The toxicity decreased with increasing periods of decomposition. After 30 days of decomposition, stimulation of growth was often obtained.

Toxic substances may also be found in soil organic matter. Kononova (64) and Krasil'nikov $(65,66)$ have shown that a number of growth- 
inhibiting substances are produced during the breakdown of organic matter. Vanillin, benzoic acid, dihydroxystearic acid, and some aldehydes are phytotoxic substances of this sort.

Phytotoxic substances can be isolated from the

\begin{tabular}{|c|c|c|c|c|}
\hline \multirow{3}{*}{ Plant material added } & \multicolumn{4}{|c|}{ After 20-day decomposition period at } \\
\hline & \multicolumn{2}{|c|}{ Saturation } & \multicolumn{2}{|c|}{ Field capacity } \\
\hline & $\mathrm{pH}_{\text {range }}^{b}$ & $\begin{array}{l}\mathrm{O}_{2} \mathrm{up}^{-} \\
\text {takec }^{c}\end{array}$ & $\mathrm{pH}$ range & $\mathrm{O}_{2}$ up- \\
\hline Soil only. & $6.4-6.6$ & 128 & $6.4-6.6$ & 131 \\
\hline Timothy & $4.8-5.2$ & 18 & $5.9-6.4$ & 90 \\
\hline Rye..... & $5.3-5.8$ & 45 & $6.0-6.6$ & 104 \\
\hline Corn. & $4.9-5.4$ & 28 & $6.0-6.5$ & 99 \\
\hline $\begin{array}{l}\text { Tobacco......... } \\
\text { Control } 125( \pm 8)^{d}\end{array}$ & $5.5-5.9$ & 68 & $6.9-7.5$ & 112 \\
\hline
\end{tabular}

a This table appeared first in Can. J. Botany $36: 621-647,1958$. See reference 96 .

${ }^{b}$ After the 20-day decomposition period; $\mathrm{pH}$ of each extract was adjusted to 5.3 prior to testing.

${ }^{c} \mathrm{O}_{2}$ uptake, in $\mu$ liters of $\mathrm{O}_{2}$ (after $6 \mathrm{hr}$ at $20 \mathrm{C}$ ), of 50 Harrow Velvet tobacco seedlings. In each instance, the tobacco seedlings were exposed for 16 $\mathrm{hr}$ to the various extracts, then returned to phosphate buffer ( $\mathrm{pH}$ 5.3) before their $\mathrm{O}_{2}$ uptake was determined. Each figure is based on the average of four different decomposition series, for each of which three determinations of four replicates were made.

${ }^{d} \mathrm{O}_{2}$ uptake, in $\mu$ liters of $\mathrm{O}_{2}$ (after $6 \mathrm{hr}$ at $20 \mathrm{C}$ ), of comparable seedlings pre-exposed $(16 \mathrm{hr})$ to 0.01 M phosphate buffer solution; based on the average of 12 determinations. soil. Mirchink (84), in a study of toxicity in turf-podzol soil, found that the water extract of soil had a depressing effect on germination and sprout length of wheat seedlings (Table 13). Extracts of soil to which lime and complete mineral fertilization had been applied did not produce this toxic effect.

McCalla et al. (83) detected water-soluble soil constituents which reduced root and shoot growth of wheat seedlings. Also, substances inhibitory to the growth of roots and shoots of wheat seedlings were isolated from methanol and acetone extracts of stubble-mulched soil. Sodium pyrophosphate extracts of soil from stubble-mulched plots at Lincoln, Neb., contained a phytotoxic substance. The use of paper, column, and gas chromatography permitted a separation of the phytotoxic substance from the crude sodium pyrophosphate extract. The substance was a neutral compound and had an $R_{F}$ value similar to that of patulin.

The foregoing examples amply demonstrate that, under appropriate conditions, phytotoxic substances are produced during decomposition of crop residues, and that phytotoxic substances can be isolated from the soil.

\section{Phytotoxic Substances in Forest Soils}

Forest soils containing an abundance of organic matter provide a favorable environment for rapid decomposition. In such an environment, numerous organic substances are formed. Persidsky and Wilde (100) found that some of the volatile substances released during decomposition of forest litter stimulated growth of excised roots of blue lupine, but others were toxic.

Neilson-Jones (89), in a study of low productivity of trees on Wareham Forest soils, observed

TABLE 13. Action of soil extracts on germination of wheat seeds*

\begin{tabular}{|c|c|c|c|c|c|}
\hline \multirow[b]{2}{*}{ Treatment } & \multicolumn{2}{|c|}{ 7/VII } & \multirow{2}{*}{ 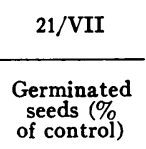 } & \multicolumn{2}{|c|}{ 7/VIII } \\
\hline & $\begin{array}{l}\text { Seed germi- } \\
\text { nation }(\% \\
\text { of control) }\end{array}$ & $\begin{array}{l}\text { Length of } \\
\text { sprouts in } \\
\mathrm{cm} \text { (avg) }\end{array}$ & & $\begin{array}{l}\text { Germinated } \\
\text { seeds (\% } \\
\text { of control) }\end{array}$ & $\begin{array}{l}\text { Length of } \\
\text { sprouts in } \\
\text { cm (avg) }\end{array}$ \\
\hline Control (water). & 100 & 5.6 & 100 & 100 & 3.2 \\
\hline Control (without fertilizer).... & 87 & 4.6 & 79 & 71 & 2.6 \\
\hline 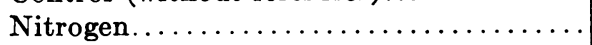 & 95 & 4.5 & 76 & 79 & 2.8 \\
\hline Lime + manure......... & 95 & 5.0 & 84 & 82 & 3.3 \\
\hline Lime + manure + NPK. & 100 & 4.9 & 100 & 89 & 3.2 \\
\hline
\end{tabular}

* This table appeared first in Microbiology USSR (Engl. Transl.) 26-83-90, 1957. See reference 84. 
the development of antifungal substances of biological origin. The effect on tree growth was thought to result from inhibition of mycorrhiza formation and consequent restriction of root growth and nutrient intake. In the laboratory, the toxic condition was developed in a soil with a high moisture content. Low temperature did not seem to be a factor in the development of the toxic condition. Autoclaving of the soil or treatment with alcohol, ether, or toluol removed the inhibitory factor. mulching leads to (i) reduced nitrate production; (ii) lowered soil temperatures in the spring (this may be detrimental to such crops as corn); and (iii) increased difficulty in the control of weeds and in other cultural operations requiring the use of machines. Even when measures are taken to offset these difficulties (such as addition of nitrogen, delayed planting of corn in the spring to minimize the temperature effect, and good control of weeds), crop yields may still be inferior under the stubble-mulch system. An additional

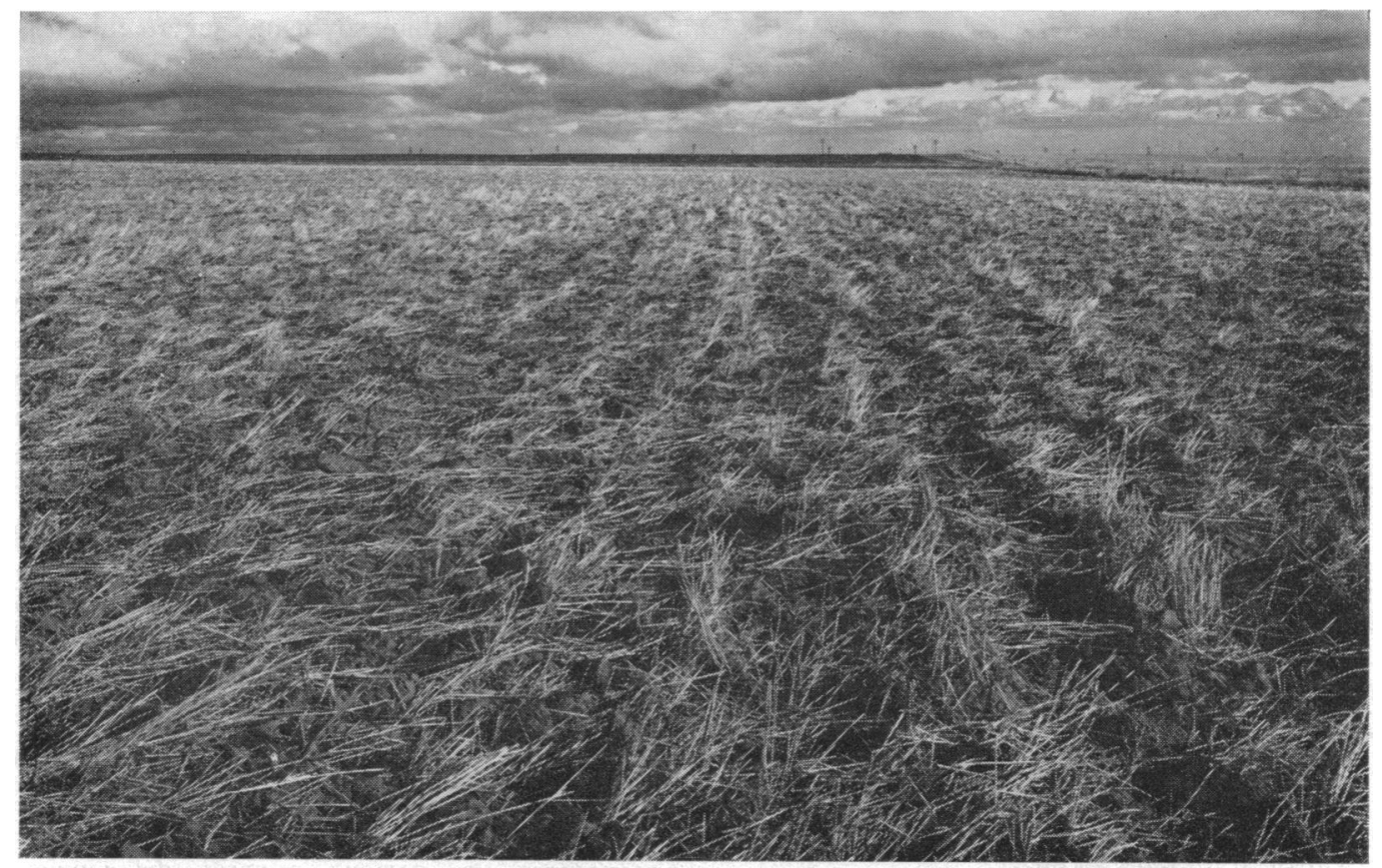

FIG. 2. Stubble-mulched field in western Nebraska. Little wind and water erosion occur with this amount of soil cover.

\section{Phytotoxic Effects Encountered in Stubble Mulching}

Stubble mulching, the use of crop residues on the surface of the soil, is a very effective method for protecting the land against erosion by wind and water (Fig. 2). However, plant growth and subsequent crop yields obtained with this system of farming are frequently reduced in comparison with growth and yields obtained by conventional plow farming, particularly in the more humid areas of the United States (80). A number of factors are involved in this reduction. For example, in comparison with plowing, stubble factor contributing to the observed yield reduction may be the presence of phytotoxic substances in residues, in soil, and among the metabolic products of soil microorganisms. As previously indicated $(49,81,82)$, most crop residues appear to contain phytotoxic substances. Also, phytotoxic substances have been isolated from stubble-mulched soil with extraction procedures involving water, methanol, acetone, and sodium pyrophosphate (83), and many soil microorganisms produce phytotoxic substances (e.g., patulin) when grown in pure culture (94). Studies are under way at Lincoln, Neb., to isolate and identify the phytotoxic substances in the soil 
TABLE 14. Influence of organic compounds on the growth of tobacco seedlings*

\begin{tabular}{|c|c|c|}
\hline Control or compound $(200 \mathrm{mg} / \mathrm{liter})$ & $\begin{array}{l}\text { Avg total } \\
\text { yield }\end{array}$ & $\underset{\text { ancet }}{\text { Appear- }}$ \\
\hline & $m g$ & \\
\hline Control. & 20.1 & $\mathrm{~S}, 8$ \\
\hline DL-Alanine... & 0.4 & - \\
\hline DL- $\alpha$-Amino- $n$-butyric acid . . . . & 0 & - \\
\hline D-Arginine hydrochloride ...... & 18.3 & $\mathrm{~S}, 8$ \\
\hline L-Asparagine . & 0.5 & $\mathrm{R}, 0$ \\
\hline L-Aspartic acid $\ldots \ldots \ldots \ldots \ldots \ldots$ & 2.0 & $\mathrm{R}, 6$ \\
\hline L-Cystine $\ldots \ldots \ldots \ldots \ldots \ldots \ldots$ & 15.6 & $\mathrm{~S}, 8$ \\
\hline D-Glutamic acid.. & 0.6 & $\mathrm{R}, 2$ \\
\hline Glutathione $\ldots \ldots \ldots \ldots \ldots \ldots$ & 1.4 & $\mathrm{R}, 2$ \\
\hline Glycine . . . . . . . . . . . & 0.5 & $\mathrm{R}, 1$ \\
\hline L-Histidine dihydrochloride..... & 4.8 & $\mathrm{R}, 8$ \\
\hline L-Hydroxyproline $\ldots \ldots \ldots \ldots$ & 0 &,- 0 \\
\hline L-Leucine $\ldots \ldots \ldots \ldots \ldots \ldots$ & 9.2 & $\mathrm{~S}, 8$ \\
\hline DL-Isoleucine $\ddagger \ldots \ldots \ldots \ldots \ldots$ & 1.8 & $\mathrm{R}, 4$ \\
\hline D-Lysine dihydrochloride $\ldots \ldots$ & 2.0 & $\mathrm{R}, 4$ \\
\hline DL-Methionine $\ldots \ldots \ldots \ldots \ldots$ & 4.8 & $\mathrm{~S}, 8$ \\
\hline DL-Norleucine $\ldots \ldots \ldots \ldots \ldots$ & 0.5 & $\mathrm{R}, 2$ \\
\hline DL-Ornithine hydrochloride. . . . & 13.9 & $\mathrm{~S}, 8$ \\
\hline DL- $\beta$-Phenylalanine $\ldots \ldots \ldots \ldots$ & 10.1 & $\mathrm{~S}, 8$ \\
\hline L-Proline $\ldots \ldots \ldots \ldots \ldots \ldots \ldots$ & 0.1 & $\mathrm{R}, 2$ \\
\hline DL-Serine $\ldots \ldots \ldots \ldots \ldots \ldots \ldots$ & 0 & - \\
\hline DL-Threonine $\ldots \ldots \ldots \ldots \ldots$ & 0.2 & $\mathrm{R}, 2$ \\
\hline L-Tryptophan $\ldots \ldots \ldots \ldots \ldots \ldots$ & 0.6 & $\mathrm{R}, 2$ \\
\hline L-Tyrosine. . . . & 10.4 & $\mathrm{~S}, 8$ \\
\hline DL-Valine $\ldots \ldots \ldots \ldots \ldots \ldots \ldots$ & 0.3 & $\mathrm{R}, 2$ \\
\hline
\end{tabular}

* Maryland Medium Broadleaf, with $2 \%$ of sucrose plus various amino acids in aseptic culture for 28 days at $25 \mathrm{C}$ and $500 \mathrm{ft}$-c of fluorescent white light for $8 \mathrm{hr}$ daily. This table appeared first in $\mathbf{J}$. Agr. Res. 75:81-92, 1947. See reference 125.

$\dagger \mathrm{S}$, shoot or stem; R, rosette. Rated from 0 (white) to 10 (dark green).

$\ddagger$ Seedlings grown with DL-isoleucine showed inhibition in growth of apical bud, suckering, and strap leaves; all are typical symptoms of frenching.

obtained from stubble-mulched plots on which reduced plant growth has been observed.

\section{Some Specific Plant Effects Possibly Caused By Toxins From Microorganisms \\ Legume Bacteria Factor in the Chlorosis of Soybeans}

Erdman et al. $(36,37)$ and Johnson et al. (58, $59,60)$ reported a bacterial-induced chlorosis of soybeans. Some soybean varieties, such as Lee, were highly susceptible. Apparently, during nodulation certain strains of rhizobium produced substances which inhibited growth and produced chlorosis of the susceptible varieties. There was some indication that chlorosis and growth inhibition were caused by different substances. Extracts of nodules from chlorotic soybean plants inoculated with chlorosis-inducing Rhizobium japonicum strain 76 retained their inhibitory activity after autoclaving for $25 \mathrm{~min}$ at $120 \mathrm{C}$ and storage at room temperature for several months. In tests involving applications of the extract to 37 species other than soybeans, severe chlorosis was observed in 7 species.

\section{Frenching Disease of Tobacco}

Valleau and Johnson (136) described "frenching" of tobacco as primarily a chlorosis of the tissue between the larger veins in the leaves near the growing point of the plant. Because the addition of nitrate nitrogen alleviated the symptoms, these investigators believed that nitrogen deficiency accounted for the disease. The addition of lime or heating the soil to $65 \mathrm{C}$ also caused the symptoms to disappear.

Steinberg (124) grew Xanthi Turkish tobacco seedlings aseptically on $50 \mathrm{ml}$ of a mineral-agar solution containing $200 \mathrm{ppm}$ of Peptone (Difco) in 200-ml Erlenmeyer flasks at 25 C. About 60 different species and strains of soil bacteria were introduced into tobacco cultures by stab inoculation near the seedling stems. Abnormal growth of various types resulted in several of the cultures. Included were chlorotic effects similar to those encountered in various mineral deficiencies; epinasty; cupped, narrow, and strap leaves; and leaves with lobes, hooked tips, and rim roll. Some of the effects were similar to typical frenching symptoms.

Steinberg $(125,126)$ also found that tobacco plants grown in a nutrient solution supplemented with various individual amino acids at a final concentration of $200 \mathrm{ppm}$ exhibited stunted growth and chlorosis to varying degrees (Table 14). The effects produced by DL-isoleucine were especially similar to typical frenching symptoms. Steinberg suggested that "excesses of free amino acid due to abnormalities in protein metabolism may contribute to the formation of characteristic patterns of symptoms in plants because of disturbances in mineral nutrition." 


\section{Replant Problem in Peaches}

The peach tree replant problem in Ontario, Canada, as described by Koch (62), is a complex one with probably no single dominant factor responsible. When an old peach orchard is replaced by young peach trees, many of the young trees become stunted in growth. The factors involved probably include soil toxins, nematodes, fungi, bacteria, soil fertility, and possibly others (138). Replants that are most severely affected are usually located at or very near the site of an old tree. For such replants, soil fumigation does produced substances that inhibited the respiration of excised peach root tips (Tables 15 and 16).

\section{Replant Problem in Citrus}

The citrus replant problem was studied extensively by Martin and co-workers $(71,76,77)$. In citrus groves affected by this condition, growth of replants is slow in comparison with growth of young trees planted in soil where citrus never has been grown. Martin (71, 72, 73, 74) believes that the reduced growth is caused

TABLE 15. Influence of incubation time, soil type, and other factors on the relative toxicity of the resulting soil leachates as determined by the intensity of their inhibiting effects on the respiration of excised peach root tips*

\begin{tabular}{|c|c|c|c|c|c|c|c|c|}
\hline \multirow{3}{*}{$\begin{array}{l}\text { Incubation time } \\
\text { (hr) at } 25 \mathrm{C} \\
\text { before extracts } \\
\text { were made }\end{array}$} & \multicolumn{7}{|c|}{ Substances added to old peach orchard soil (site area) } & \multirow{3}{*}{$\begin{array}{l}\text { Peach root residue } \\
(2 \%) \text { added to } \\
\text { "compost soil" }\end{array}$} \\
\hline & \multicolumn{2}{|c|}{ Peach root residue } & \multicolumn{2}{|c|}{ Amygdalin $(0.25 \%)$} & \multicolumn{2}{|c|}{ Peach soil autoclaved } & \multirow{2}{*}{$\begin{array}{l}\text { Sour cherry } \\
\text { root residue } \\
(2 \%)\end{array}$} & \\
\hline & $2 \% \dagger$ & $5 \%$ & $\begin{array}{l}\text { Site area } \\
\text { soil }\end{array}$ & $\begin{array}{c}\text { Intersite } \\
\text { area soil }\end{array}$ & $\begin{array}{l}\text { Peach root } \\
\text { residue } \\
(2 \%)\end{array}$ & $\underset{(0.25 \%)}{\text { Amygdalin }}$ & & \\
\hline 60 & 48 & - & 51 & - & - & - & - & - \\
\hline 70 & 60 & 一 & 55 & 一 & 8 & $10 \mathrm{sT}$ & $8 \mathrm{sT}$ & - \\
\hline 100 & 40 & 78 & 72 & - & 6 & $15 \mathrm{sT}$ & - & $18 \mathrm{sT}$ \\
\hline 150 & - & 68 & 82 & $7 \mathrm{sT} \ddagger$ & $3 \mathrm{sT}$ & $7 \mathrm{sT}$ & $15 \mathrm{sT}$ & $25 \mathrm{sT}$ \\
\hline 200 & - & 59 & 73 & $19 \mathrm{sT}$ & - & - & 2 & - \\
\hline 300 & - & - & 74 & 14 & - & 12 & - & - \\
\hline
\end{tabular}

* This table appeared first in Can. J. Botany 33:461-486, 1955. See reference 95. Results are expressed as per cent total inhibition (or stimulation) of respiration in $5 \mathrm{hr}$ at $20 \mathrm{C}$ of 15 excised peach root tips placed in the various soil-water leachates (containing varying amounts of the decomposition products of the substances indicated). Per cent inhibition was calculated in the usual manner by using as check (or normal respiration rate) the respiration of identical root tip samples placed in soil-water leachates containing none of these products.

$\dagger$ Amount of peach root residues, amygdalin, or other root residues, calculated as per cent by weight of the total soil contents of the flask, added to each flask.

$\ddagger$ If total $\mathrm{O}_{2}$ uptake was greater than that of the check, it was calculated as per cent total stimulation (ST) of respiration.

not completely eliminate stunted growth. Proebsting and Gilmore (105) demonstrated that a toxic factor is present in peach root bark. Later, Patrick (95) and Patrick and Koch (96) suggested that the growth inhibition is caused indirectly by the cyanophoric $\beta$-glycoside, amygdalin, which is present in peach roots. Amygdalin itself is not toxic, but when broken down it yields glucose, benzaldehyde, and hydrogen cyanide, and toxicity results. The peach root and various microorganisms contain enzymes which will break down amygdalin. Patrick (95) reported that microbial decomposition of peach roots primarily by the development of plant root parasites in the soil but that other factors, including nutritional deficiencies and imbalances and deterioration of soil structure, influence the extent of injury caused by the detrimental organisms. Citrus seedlings in old citrus soils supporting very poor growth of replants did not respond to fertilization with $\mathrm{P}, \mathrm{K}, \mathrm{Mg}, \mathrm{Cu}, \mathrm{B}$, $\mathrm{Zn}$, or Mn. The poor growth occurred even when good practices of fertilizer application, pest control, and general management were used. Partial soil sterilization with such fumigants as D-D (a mixture of dichloropropane and dichloro- 
TABLE 16. Comparison between the intensity of the inhibiting effects on the respiration of peach root tips produced by decomposition products of peach root residues, amygdalin, and other root residues as influenced by incubation time and soil type*

\begin{tabular}{|c|c|c|c|c|c|c|c|c|c|c|}
\hline \multirow{3}{*}{$\begin{array}{c}\text { Incubation } \\
\text { time (hr) at } \\
25 \mathrm{Cbefore} \\
\text { extracts were } \\
\text { made }\end{array}$} & \multicolumn{9}{|c|}{ Substances added to old peach orchard soil (site area) } & \multirow{3}{*}{$\begin{array}{l}\text { Peach root } \\
\text { residue } \\
(5 \%) \\
\text { added to } \\
\text { muck soil }\end{array}$} \\
\hline & \multicolumn{2}{|c|}{$\begin{array}{l}\text { Peach root } \\
\text { residue }\end{array}$} & \multirow{2}{*}{$\begin{array}{c}\text { Amygda- } \\
\text { lin } \\
(0.25 \%)\end{array}$} & \multicolumn{2}{|c|}{ Peach soil autcclaved } & \multirow{2}{*}{$\begin{array}{l}\text { Sour } \\
\text { cherry } \\
\text { root } \\
\text { residue } \\
(2 \%)\end{array}$} & \multirow{2}{*}{$\begin{array}{l}\text { Tobacco } \\
\text { root } \\
\text { residue } \\
(10 \%)\end{array}$} & \multirow{2}{*}{$\begin{array}{c}\text { Pepper } \\
\text { root } \\
\text { residue } \\
(10 \%)\end{array}$} & \multirow{2}{*}{$\begin{array}{l}\text { Calcium } \\
\text { cyanide }\end{array}$} & \\
\hline & $1 \%$ & $5 \%$ & & $\begin{array}{l}\text { Peach root } \\
\text { residue } \\
(5 \%)\end{array}$ & $\underset{(0.25 \%)}{\text { Amygdalin }}$ & & & & & \\
\hline 40 & 63 & 66 & - & $10 \mathrm{sT}$ & - & - & $27 \mathrm{sT}$ & $36 \mathrm{sT}$ & 40 & - \\
\hline 60 & 68 & 76 & - & 12 & $4 \mathrm{sT}$ & $4 \mathrm{sT}$ & - & - & - & 6 \\
\hline 70 & - & 84 & 47 & 5 & $12 \mathrm{sT}$ & - & $28 \mathrm{sT}$ & - & - & 3 \\
\hline 80 & 55 & 81 & - & 14 & - & 7 & - & $30 \mathrm{sT}$ & - & - \\
\hline 90 & 43 & 90 & 65 & 3 sT & 5 & - & $10 \mathrm{ST}$ & - & 29 & 7 \\
\hline 110 & - & 83 & 68 & - & 13 & 5 & - & - & - & - \\
\hline
\end{tabular}

* This table appeared first in Can. J. Bot. 33:461-486, 1955. See reference 95. Results are expressed as per cent total inhibition (or stimulation) of respiration in $5 \mathrm{hr}$ at $30 \mathrm{C}$. The method used to compare the inhibiting or stimulating (sT) effects on the respiration of peach root tips produced by the different leachates is identical to that in Table 15, the only difference being that the respiration studies were carried out at $30 \mathrm{C}$ on eight excised peach root radicals.

propylene), chloropicrin, carbon disulfide, and ethylene dichloride usually resulted in improved growth of citrus seedlings, but in early tests the seedlings were still inferior to those grown on noncitrus soils. Some fumigation treatments changed the fungus populations drastically without improving plant growth. Results of experiments in which fumigated soil was inoculated with various fungi indicated that fungal species differed considerably in their influence on growth of citrus seedlings (Table 17).

Martin (74) used various leaching treatments on old citrus soil and observed the growth of citrus seedlings subsequently planted in the soil. Leaching the soil with large amounts of distilled water did not improve growth of the seedlings. However, complete recovery of seedling growth was observed in soil leached with $2 \% \mathrm{H}_{2} \mathrm{SO}_{4}$ or $2 \% \mathrm{KOH}$ followed by saturation of the soil colloids with a favorable combination of $\mathrm{Ca}, \mathrm{Mg}$, $\mathrm{K}$, and $\mathrm{H}$. As a result of these observations, Martin $(72,74)$ suggested that toxic substances originating from roots or from organisms decomposing roots might possibly be a contributing factor to the replant problem. Certain fungi, primarily Fusarium solani, Pyrenochaeta sp., and Fungus D1 were more numerous in old citrus soil than in noncitrus soil. The chemical composition of citrus seedlings grown in some old citrus soil did not differ significantly from that of
TABLE 17. Effect of fumigation and inoculation with species of soil fungi, separately and in various combinations, on growth of sweet orange seedlings in Yolo sandy loam (test 2)*

\begin{tabular}{|c|c|}
\hline Soil treatment & Dry wt of tops $\dagger$ \\
\hline & B \\
\hline$\ldots \ldots \ldots \ldots \ldots \ldots$ & 17 \\
\hline Fumigated. . . . . $\ldots \ldots \ldots \ldots \ldots$ & 24 \\
\hline \multicolumn{2}{|l|}{ Fumigated and inoculated with } \\
\hline Pyrenochaeta sp.............. & 25 \\
\hline Thielaviopsis basicola. & 5 \\
\hline Fusarium solani..... & 24 \\
\hline 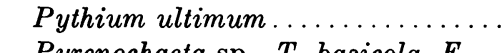 & 21 \\
\hline $\begin{array}{l}\text { Pyrenochaeta sp., T. basicola, } F \text {. } \\
\text { solani, and } P . \text { ultimum } \ldots \ldots\end{array}$ & 13 \\
\hline
\end{tabular}

* Only old citrus soil used. This table appeared first in Soil Sci. 81:259-267, 1956. See reference 78. Published with permission of The Williams \& Wil. kins Co.

$\dagger$ Average per 3-gal pot of soil. LSD 5\% $=4 \mathrm{~g}$.

seedlings grown in noncitrus soil. Old citrus soils were not toxic to numerous other crops.

Martin et al. (75) found an occasional temporary growth inhibition of citrus seedlings after heat or fumigation treatment of soils in the greenhouse or in field nursery beds. The toxic effect lasted from a few weeks to 1 year. A suggested explanation for the phenomenon was that the inhibitory substance was produced by an 
organism which became dominant after the existing population was destroyed by the treatment. The toxic substance continued to be produced until the organism involved was reduced dead roots added. Benedict suggested that inhibitory substances accumulate in the soil or other medium where bromegrass is grown. He believed that such substances are excreted from living

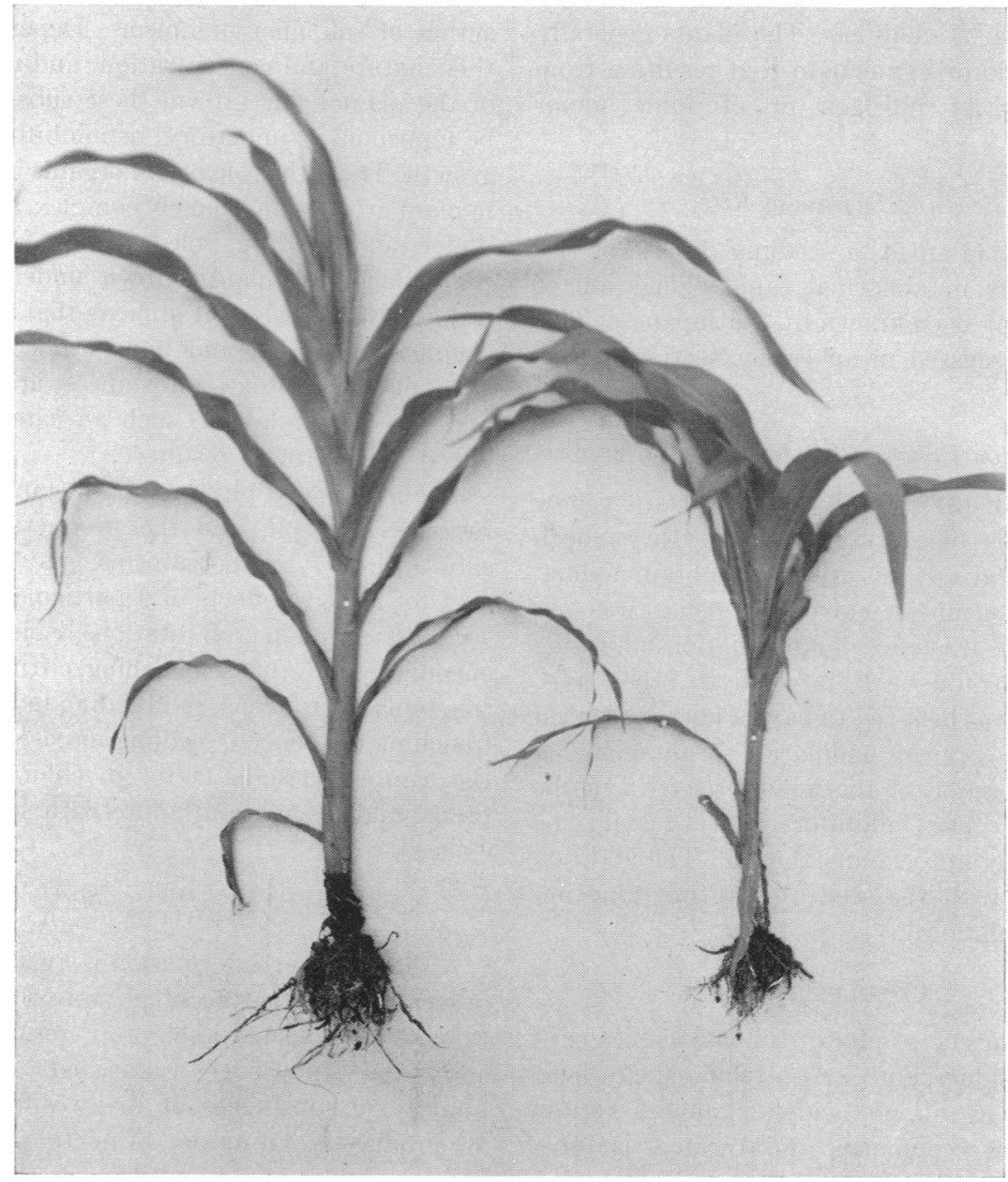

FIG. 3. Influence of stubble mulching on corn growth at Lincoln, Neb., May, 1958. (left) Typical stalk from plowed plot; (right) stunted stalk from stubble-mulched plot.

in numbers and activity by antagonistic organisms.

\section{Sod-Binding of Bromegrass}

Benedict (9) observed growth depression of bromegrass (Bromus inermis) grown in pure or mixed stands in sand culture. The degree of depression was related to the proportion of bromegrass plants in the stand. Also, the addition of dead bromegrass roots to bromegrass growing in sand culture caused a depression in growth, the extent of which was related to the amount of roots, are liberated from dead cells sloughed off from living roots, or are formed by the decomposition of these dead cells.

\section{Stunting of Corn Associated with Stubble Mulching}

In the stubble-mulch system of farming, corn grown in the humid northern areas of the United States seems to be particularly retarded in growth (80). At Lincoln, Neb., corn in a corn, oats, and wheat rotation is severely retarded about every 3 or 4 years. The retardation is evident at the 
seedling stage, and the plants seem never to recover fully. The toxic effect is not uniform over the entire stubble-mulched plot (Fig. 1). Only a few plants seem to be severely affected (Fig. 3). Such stalks at maturity may be only a foot tall and may bear a small ear. The plants generally display a chlorosis similar to that resulting from a deficiency of nitrogen or of some minor elements.

\section{Seedling Disease of Rice}

The bakanae effect, a seedling disease of rice which results in abnormal rapid elongation of stem, has long been known by the Japanese. This disease is discussed in an earlier section of this review.

\section{Inoculation Failure in Subterranean Clover}

Hely et al. (51) found that in certain yellow podzolic soils of granite origin in New South Wales, Australia, it was difficult to obtain nodulation of subterranean clover. Evidence was obtained for the existence of a nodulation-inhibiting factor that could be transferred to other soils. This factor was believed to have a microbiological origin, and to prevent nodulation by antagonizing the multiplication of the nodule bacteria in the rhizosphere. The inhibitory effect could be eliminated by autoclaving the soil. The addition of charcoal with the seed at planting time improved nodulation.

\section{Conclusions}

A wide variety of phytotoxic substances exist in plant residues and seeds. Included are such compounds as amino acids, alkaloids, certain essential oils, coumarin, unsaturated lactones such as parasorbic acid, phenols and aldehydes, organic acids, ammonia, hydrogen cyanide, mustard oils, scopoletin and scopoletin glycosides, and ethylene. Soil microorganisms also produce many organic substances which are toxic to plant growth. Examples are organic and amino acids, numerous antibiotics, and substances such as gibberellin. Toxic inorganic compounds, such as nitrites, carbon dioxide, and hydrogen sulfide, are also produced by soil microorganisms.

Although green plants can live autotrophically, it is apparent that under suitable conditions they can also live heterotrophically, absorbing organic compounds from their surroundings and me- tabolizing these compounds. Plants grown in the soil are normally exposed to a tremendous variety of organic compounds which have come directly from plant and animal residues in the soil, or indirectly from these residues through the action of soil microorganisms. Depending upon their nature and concentration, and on the kind of the plant being grown, these substances may be innocuous, stimulatory, or inhibitory to plant growth. Thus, the role of soil organic constituents in plant growth is extremely complex, and present understanding of this role is at best fragmentary, particularly for plants grown under field conditions. Nevertheless, it appears that under some chemical, physical, and biological conditions in the field, phytotoxic substances are produced and can accumulate to such an extent that reduced plant growth results.

The presence of phytotoxic substances in plant residues and soil, and the production of such substances by microorganisms, may account in part for adverse effects of a particular crop on a succeeding crop in crop rotations, yield reductions encountered in stubble mulching, citrus and peach tree replant problems, sod binding in bromegrass, frenching of tobacco, seedling disease of tobacco, the legume bacteria factor in chlorosis of soybeans, and inoculation failure with subterranean clover.

\section{OUTLOOK}

Although some information is available on the occurrence and nature of phytotoxic substances in microorganisms and crop residues, much additional knowledge is needed. Apparently, phytotoxic substances of many different kinds are produced by a myriad of microorganisms and higher plants. A knowledge of the chemical nature of these phytotoxic substances is needed in order that the substances may be precisely tested, individually and in combination, for their effects on various kinds of plants at all stages of growth. The information obtained in such tests would be useful agronomically, for example, in contributing to an understanding of the results obtained with various crop rotations. Furthermore, such information would be important ecologically, inasmuch as naturally occurring phytotoxic substances no doubt influence plant succession.

Phytotoxic substances from higher plants and microorganisms also would be expected to affect 
microbial ecology. Taxonomic information on the soil microorganisms that produce phytotoxic substances and on those that are affected by such substances is badly needed.

The isolation and identification of new phytotoxic substances will undoubtedly result in the discovery of some new compounds suitable for use in the control and management of both plants and microorganisms. Quite possibly some of these compounds may be at least as effective as presently used herbicides and fungicides, and they may be free of some of the undesirable attributes of currently popular compounds. This area of research is complex, and much work will be needed before all aspects of the interaction of the phytotoxic substances with plants and microorganisms can be understood.

\section{Literature Cited}

1. Alexander, M. 1961. Introduction to soil microbiology, p. 285 and 370. John Wiley \& Sons, Inc., New York.

2. Anonymous. 1940. Plant growth-substances in soil and manure. Soils Fertilizers 3:243244.

3. Audus, L. J. 1959. Plant growth substances, 2nd ed. Interscience Publishers, Inc., New York.

4. Audus, L. J., And J. H. Quastel. 1947. Toxic effects of amino acids and amines on seedling growth. Nature 160:222-223.

5. Barnum, C. C. 1924. The production of substances toxic to plants by Penicillium expansum link. Phytopathology 14 :238-243.

6. Barton, L. V., and J. MacNab. 1954. Effect of antibiotics on plant growth. Contrib. Boyce Thompson Inst. 17:419-434.

7. Barton, L. V., and M. L. Solt. 1948. Growth inhibitors in seeds. Contrib. Boyce Thompson Inst. 15:259-278.

8. Behmer, D. E., and T. M. McCalla. 1963. The inhibition of seedling growth by crop residues in soil inoculated with Penicillium urticae Bainer. Plant Soil 18:199-206.

9. Benedict, H. M. 1941. The inhibiting effect of dead roots on the growth of bromegrass. Agron. J. 33:1108-1109.

10. Bennett, E. L., And J. Bonner. 1953. Isolation of plant growth inhibitors from Thamnosma montana. Am. J. Botany 40:2933.

11. Bentley, J. A. 1958. The naturally-occurring auxins and inhibitors. Ann. Rev. Plant Physiol. 9:47-80.

12. Bonner, J. 1950. The role of toxic substances in the interactions of higher plants. Botan. Rev. 16:51-65.

13. Bonner, J., And A. W. Galston. 1944. Toxic substances from the culture media of guayule which may inhibit growth. Botan. Gaz. 106:185-198.

14. Borner, H. 1960. Liberation of organic substances from higher plants and their role in the soil sickness problem. Botan. Rev. 26: $393-424$.

15. Boynton, D. 1941. Soils in relation to fruitgrowing in New York. XV. Seasonal and soil influences on oxygen and carbondioxide levels of New York orchard soils. Cornell Univ. Agr. Expt. Sta. Bull. 763: $1-43$.

16. Breazeale, J. F. 1924. The injurious aftereffects of sorghum. Agron. J. 16:689-700.

17. Brian, P. W. 1949. The production of antibiotics by microorganisms in relation to biological equilibria in soil. Symp. Soc. Exptl. Biol. 3:357-372.

18. Brian, P. W. 1957. Effects of antibiotics on plants. Ann. Rev. Plant Physiol. 8:413-426.

19. Brian, P. W. 1957. The ecological significance of antibiotic production, p. 168-188. In R. E. O. Williams and C. C. Spicer [ed.], Microbial ecology. Cambridge University Press, New York.

20. Brian, P. W., G. W. Elson, H. G. Hemming, and M. Radley. 1954. The plant-growthpromoting properties of gibberellic acid, a metabolic product of the fungus Gibberella fujikuroi. J. Sci. Food Agr. 5:602-612.

21. Brian, P. W., J. M. Wright, J. Stubbs, and A. M. WAY. 1951. Uptake of antibiotic metabolites of soil microorganisms by plants. Nature $167: 347-349$.

22. Brown, J. C. 1961. Iron chlorosis in plants. Advan. Agron. 13: 329-369.

23. Campbell, A. G. 1959. A germination inhibitor and root-growth retarder in chou moellier (Brassica oleracea var.). Nature 183: 1263-1264.

24. Chang, H. T., and W. E. Loomis. 1945. Effect of carbon dioxide on absorption of water and nutrients by roots. Plant Physiol. 20: 221-232.

25. Cochrane, V. W. 1949. Crop residues as causative agents of root rots of vegetables. Conn. Agr. Expt. Sta. (New Haven) Bull. 526:1-34.

26. Collison, R. C. 1925. The presence of certain organic compounds in plants and their rela. tion to the growth of other plants. Agron. J. 17:58-68.

27. Collison, R. C., And H. J. Conn. 1925. The effect of straw on plant growth. N.Y. State 
Agr. Expt. Sta. (Geneva, N.Y.) Tech. Bull. 114:1-35.

28. Cooper, R. 1959. Bacterial fertilizers in the Soviet Union. Soils Fertilizers $22: 327-333$.

29. Cox, L. G., H. M. Munger, and E. A. Sмith. 1945. A germination inhibitor in the seed coats of certain varieties of cabbage. Plant Physiol. 20:289-294.

30. Curtis, R. W. 1957. Survey of fungi and actinomycetes for compounds possessing gibberellinlike activity. Science 125:646.

31. Curtis, R. W. 1957. Translocatable plant growth inhibitors produced by Penicillium thomii and Arachniotus trisporus. Plant Physiol. 32 :56-59.

32. Curtis, R. W. 1958. Root curvatures induced by culture filtrates of Aspergillus niger. Science 128:661-662.

33. Curtis, R. W. 1958. Curvatures and malformations in bean plants caused by culture filtrate of Aspergillus niger. Plant Physiol. 33:17-22.

34. Doryland, C. J. T. 1916. The influence of energy material upon the relation of soil microorganisms to soluble plant food. N. Dakota Agr. Expt. Sta. Bull. 116:319-401.

35. Engard, C. J., And A. H. Nakata. 1947. A growth inhibitor and a growth promotor in sugar cane. Science 105:577-580.

36. Erdman, L. W., H. W. Johnson, and F. Clark. 1956. A bacterial-induced chlorosis in the Lee soybean. Plant Disease Reptr. $40: 646$.

37. Erdman, L. W., H. W. Johnson, and F. Clark. 1957. Varietal responses of soybeans to a bacterial-induced chlorosis. Agron. J. 49:267-271.

38. Evans, E., ANd D. Gottlieb. 1955. Gliotoxin in soils. Soil Sci. 80:295-301.

39. Evenari, M. 1949. Germination inhibitors. Botan. Rev. 15:153-194.

40. FAнMY, T. 1923. The production by Fusarium solani of a toxic excretory substance capable of causing wilting in plants. Phytopathology 13:543-550.

41. Fraps, G. S. 1915. Effect of organic compounds in pot experiments. Texas Agr. Expt. Sta. Bull. 174:1-13.

42. Funchess, M. J. 1916. The effects of certain organic compounds on plant growth. Alabama Agr. Expt. Sta. Bull. 191:103-132.

43. GarB, S. 1961. Differential growth-inhibitors produced by plants. Botan. Rev. 27: $422-443$.

44. Goldberg, H. S. 1959. Antibiotics: their chemistry and nonmedical uses, p. 356-365. D. Van Nostrand Co., Inc., Princeton, N.J.
45. Gottlieb, D., P. Siminoff, and M. M. Martin. 1952. The production and role of antibiotics in soil. IV. Actidione and clavacin. Phytopathology 42:493-496.

46. Gray, R., AND J. Bonner. 1948. An inhibitor of plant growth from the leaves of Encelia farinosa. Am. J. Botany 35:52-57.

47. Gray, R., AND J. Bonner. 1948. Structure determination and synthesis of a plant growth inhibitor, 3 - acetyl - 6 - methoxybenzaldehyde, found in the leaves of Encelia farinosa. J. Am. Chem. Soc. 70:1249-1253.

48. Grossbard, E. 1952. Antibiotic production by fungi on organic manures and in soil. J. Gen. Microbiol. 6:295-310.

49. Guenzi, W. D., and T. M. McCalla. 1962. Inhibition of germination and seedling development by crop residues. Soil Sci. Soc. Am. Proc. 26:456-458.

50. HAtA, K. 1962. Studies on plant growth accelerating substances. I. The isolation method of soil microbes which produce plant growth accelerating substances. Agr. Biol. Chem. (Tokyo) 26:278-287.

51. Hely, F. W., F. J. Bergersen, ANd J. BrockWELL. 1957. Microbial antagonism in the rhizosphere as a factor in the failure of inoculation of subterranean clover. Australian J. Agr. Res. 8:24-44.

52. Hessayon, D. G. 1953. Fungitoxins in the soil. I. Historical. Soil Sci. 75:317-327.

53. Hessayon, D. G. 1953. Fungitoxins in the soil. II. Trichothecin, its production and inactivation in unsterilized soils. Soil Sci. 75:395-404.

54. Hodgson, R., A. J. Riker, AND W. H. Peterson. 1947. A wilt-inducing toxic substance from crown-gall bacteria. Phytopathology $37: 301-318$.

55. Jameson, D. A. 1961. Growth inhibitors in native plants of northern Arizona. U.S. Rocky Mountain Forest and Range Expt. Sta. Res. Notes 61:1-2.

56. JefFerys, E. G. 1952. The stability of antibiotics in soils. J. Gen. Microbiol. 7:295312.

57. Jefferys, E. G., and P. W. Brian. 1954. Are antibiotics produced in soil? Congr. Intern. Botan. 8th, Paris, 1954, Rappt. Commun. Sec. 24, p. 71-72.

58. Johnson, H. W., and F. E. Clark. 1958. Role of the root nodule in the bacterial-induced chlorosis of soybeans. Soil Sci. Soc. Am. Proc. 22:527-528.

59. Johnson, H. W., U. M. Means, and F. E. Clark. 1958. Factors affecting the expression of bacterial-induced chlorosis of soybeans. Agron. J. 60:571-574. 
60. Johnson, H. W., U. M. Means, and F. E. Clark. 1959. Responses of seedlings to extracts of soybean nodules bearing selected strains of Rhizobium japonicum. Nature 183:308-309.

61. KeY, J. L., and D. S. Galitz. 1959. Growth inhibitor in immature soybean seeds and 2,4-D-sprayed soybean seedlings. Science 130:1340-1341.

62. КосH, L. W. 1955. The peach replant problem in Ontario. I. Symptomatology and dis. tribution. Can. J. Botany 33: 450-460.

63. KoIke, H. 1961. The accumulation of nitrite in Hawaiian soils. Bacteriol. Proc., p. 55.

64. Kononova, M. M. 1961. Soil organic matter, its nature, its role in soil formation and in soil fertility, p. 165. Pergamon Press, New York.

65. Krasil'nikov, N. A. 1957. On the importance of soil microorganisms in plant nutrition (on contributions by Soviet microbiologists in 40 years). Microbiology USSR (Engl. Transl.) 26:637-650.

66. Krasil'nikov, N. A. 1958. Soil microorganisms and higher plants, p. 330-339. Office of Technical Services, U.S. Dept. Commerce, Washington, D.C.

67. LeFevre, C. W., and C. O. Clagett. 1961. Further studies on the growth inhibitor from quackgrass. Plant Physiol. 36 (Suppl.): IX.

68. LeTourneau, D., G. D. Failes, and H. G. HEgGeness. 1956. The effect of aqueous extracts of plant tissue on germination of seeds and growth of seedlings. Weeds 4: 363-368.

69. LochHead, A. G. 1958. Soil bacteria and growth-promoting substances. Bacteriol. Rev. 22:145-153.

70. Marth, P. C., W. V. Audia, and J. W. Mitchell. 1956. Effects of gibberellic acid on growth and development of plants of various genera and species. Botan. Gaz. 118:106-111.

71. Martin, J. P. 1947. Fungus flora of some California soils in relation to slow decline of citrus trees. Soil Sci. Soc. Am. Proc. $12: 209$ 214.

72. Martin, J. P. 1948. Effect of fumigation, fertilization, and various other soil treatments on growth of orange seedlings in old citrus soils. Soil Sci. 66:273-288.

73. Martin, J. P. 1949. Effect of soil fungi on germination of sweet orange seeds and development of the young seedlings. Soil Sci. Soc. Am. Proc. 14:184-188.

74. Martin, J. P. 1950. Effect of various leaching treatments on growth of orange seedlings in old citrus soils. Soil Sci. 69: 433-442.

75. Martin, J. P., R. C. Baines, and A. L. Page. 1963. Observation on the occasional temporary growth inhibition of citrus seedlings following heat or fumigation treatment of soil. Soil Sci. 95:175-185.

76. Martin, J. P., and W. P. Bitters. 1962. Greenhouse citrus replant studies with various rootstock seedlings and rootstockscion combinations. Proc. Am. Soc. Hort. Sci. $80: 274-284$.

77. Martin, J. P., and J. O. Ervin. 1958. Changes in fungus population of California old citrus orchard soils when cropped to orange seedlings in the greenhouse. Soil Sci. 86:152-155.

78. Martin, J. P., L. J. Klotz, T. A. DeWolfe, AND J. O. ERvin. 1956. Influence of some common soil fungi on growth of citrus seedlings. Soil Sci. $81: 259-267$.

79. Mayer, A. M., and A. Poljakoff-Mayber. 1961. Coumarins and their role in growth and germination. Intern. Conf. Plant Growth Regulation, 4th, p. 735-750. Iowa State University Press, Ames.

80. McCalla, T. M., and T. J. Army. 1961. Stubble mulch farming. Advan. Agron. 13:125-196.

81. McCalla, T. M., and F. L. Duley. 1948. Stubble mulch studies: effect of sweetclover extract on corn germination. Science 108:163.

82. McCalla, T. M., and F. L. Duley. 1949. Stubble mulch studies. III. Influence of soil microorganisms and crop residues on the germination, growth and direction of root growth of corn seedlings. Soil Sci. Soc. Am. Proc. 14:196-199.

83. McCalla, T. M., W. D. Guenzi, and F. A. Norstadt. 1963. Microbial studies of phytotoxic substances in the stubble-mulch system. Z. Allgem. Mikrobiol. 3:202-210.

84. Mirchink, T. G. 1957. On fungi causing toxicity of turf-podzol soil in various stages of cultivation. Microbiology USSR (Engl. Transl.) 26:83-90.

85. Morgan, D. G., and G. C. Mees. 1956. Gibberellic acid and the growth of crop plants. Nature 178:1356-1357.

86. Murashige, T., R. A. Hamilton, and I. T. Kunisski. 1962. Papaya retards Macadamia growth. Hawaii Farm Sci. 11:1-2.

87. MurRay, T. J. 1921. The effect of straw on the biological soil processes. Soil Sci. 12 :233259.

88. Myers, H. E., ANd K. L. Anderson. 1942. 
Bromegrass toxicity vs. nitrogen starvation. J. Am. Soc. Agron. 34:770-773.

89. Neilson-Jones, W. 1941. Biological aspects of soil fertility. J. Agr. Sci. 31:379-411.

90. Newman, A. S., and A. G. Norman. 1943. The activity of subsurface soil populations. Soil Sci. 55:377-391.

91. Nickell, L. G., ANd A. C. Finlay. 1954. Antibiotics and their effects on plant growth. J. Agr. Food Chem. 2:178-182.

92. Nielsen, K. F., T. F. Cuddy, and W. B. Woods. 1960. The influence of the extract of some crops and soil residues on germination and growth. Can. J. Plant Sci. 40:188197.

93. Norman, A. G. 1959. Inhibition of root growth and cation uptake by antibiotics. Soil Sci. Soc. Am. Proc. $23: 368-370$.

94. Norstadt, F. A., and T. M. McCalla. 1963. A phytotoxic substance from a species of Penicillium. Science 140:410-411.

95. Patrick, Z. A. 1955. The peach replant problem in Ontario. II. Toxic substances from microbial decomposition products of peach root residues. Can. J. Botany 33:461-486.

96. Patrick, Z. A., ANd L. W. Koch. 1958. Inhibition of respiration, germination, and growth by substances arising during the decomposition of certain plant residues in the soil. Can. J. Botany 36:621-647.

97. Patrick, Z. A., T. A. Toussoun, And W. C. SNYDER. 1963. Phytotoxic substances in arable soils associated with decomposition of plant residues. Phytopathology 53: 152-161.

98. Paul, E. A., and E. L. Schmidt. 1960. Extraction of free amino acids from soil. Soil Sci. Soc. Am. Proc. 24 :195-198.

99. Payne, T. M. B., J. W. Rouatt, and H. Katznelson. 1956. Detection of free amino acids in soil. Soil Sci. $82: 521-524$.

100. Persidsky, D. J., And S. A. Wilde. 1954. The effect of volatile substances released by soil, humus, and composts on the growth of excised roots. Plant Physiol. 29:484-486.

101. Pinck, L. A., W. F. Holton, And F. E. Allison. 1961. Antibiotics in soils. I. Physico-chemical studies of antibiotic-clay complexes. Soil Sci. $91: 22-28$.

102. Pinck, L. A., D. A. Soulides, and F. E. Allison. 1961. Antibiotics in soils. II. Extent and mechanism of release. Soil Sci. 91:94-99.

103. Postlethwait, S. N., and R. W. Curtis. 1959. Histology of malformations produced on bean plants by culture filtrate of $A s$ pergillus niger. Am. J. Botany 46:31-35.
104. Prill, E. A., L. V. Barton, and M. L. Solt. 1949. Effects of some organic acids on the growth of wheat roots in solutions. Contrib. Boyce Thompson Inst. 15:429-435.

105. Proebsting, E. L., and A. E. Gilmore. 1940. The relation of peach root toxicity to the re-establishing of peach orchards. Proc. Am. Soc. Hort. Sci. 38:21-26.

106. Putnam, H. D., and E. L. Schmidt. 1959. Studies on the free amino acid fraction of soils. Soil Sci. $87: 22-27$.

107. Riker, A. J., And A. E. Gutsche. 1948. The growth of sunflower tissue in vitro on synthetic media with various organic and inorganic sources of nitrogen. Am. J. Botany $35: 227-238$.

108. Routley, D. G., and J. T. Sullivan. 1960. Toxic and nutritional effects of organic compounds on ladino clover seedlings. Agron. J. 52:317-319.

109. Ryan, G. F., G. Greenblatt, and K. A. Al-Delaimy. 1961. Seedling albinism induced by an extract of Alternaria tenuis. Science 134:833-834.

110. Sснміd , E. L. 1951. Soil microorganisms and plant growth substances. I. Historical. Soil Sci. 71:129-140.

111. Schreiner, O., ANd H. S. Reed. 1907. Some factors influencing soil fertility. U.S. Dept. Agr. Bur. Soils Bull. 40:1-40.

112. Schreiner, O., AND H. S. Reed. 1908. The toxic action of certain organic plant constituents. Botan. Gaz. 45:73-102.

113. Schreiner, O., ANd E. C. Shorey. 1909. The isolation of harmful organic substances from soils. U.S. Dept. Agr. Bur. Soils Bull. 53:1-53.

114. Schreiner, O., ANd J. J. Skinner. 1910. Some effects of a harmful organic soil constituent. U.S. Dept. Agr. Bur. Soils Bull. 70:1-98.

115. Schwartz, S. M., J. E. Varner, and W. P. Martin. 1954. Separation of organic acids from several dormant and incubated Ohio soils. Soil Sci. Soc. Am. Proc. 18:174-177.

116. Sсотт, R. A. 1961. "Crazy top" causes and treatment, p. 16. Cotton Gin \& Oil Mill Press.

117. Siegel, S. M. 1950. Germination and growth inhibitors from red kidney bean seed. Botan. Gaz. 111:353-356.

118. Skinner, J. J. 1918. Soil aldehydes-a scientific study of a new class of soil constituents unfavorable to crops, their occurrence, properties and elimination in practical agriculture. J. Franklin Inst. 186:165-186, 289$316,547,584,723-741,1111-1116$. 
119. Skinner, J. J., And C. F. Noll. 1916. Field tests of fertilizer action on soil aldehydes. J. Am. Soc. Agron. 8:273-298.

120. Sмітн, L. 1948. The effect of chaff of cereals on germination of seeds and on the growth of mold. J. Am. Soc. Agron. 40:32-44.

121. Soulides, D. A., L. A. Pinck, And F. E. Allison. 1961. Antibiotics in soils. 3. Further studies on release of antibiotics from clays. Soil Sci. 92:90-93.

122. Stallings, J. H. 1954. Soil produced antibiotics-plant disease and insect control. Bacteriol. Rev. 18:131-146.

123. StaRKey, R. L. 1958. Interrelations between microorganisms and plant roots in the rhizosphere. Bacteriol. Rev. $22: 154-172$.

124. Steinberg, R. A. 1947. Growth responses of tobacco seedlings in aseptic culture to diffusates of some common soil bacteria. J. Agr. Res. 75:199-206.

125. Steinberg, R. A. 1947. Growth responses to organic compounds by tobacco seedlings in aseptic culture. J. Agr. Res. 75:81-92.

126. Steinberg, R. A. 1951. Amino acid toxicities to tobacco varieties differing in resistance to black root-rot. Torrey Botan. Club Bull. 78:227-232.

127. Stevenson, F. J. 1956. Isolation and identification of some amino compounds in soils. Soil Sci. Soc. Am. Proc. 20:201-204.

128. Stevenson, I. L. 1954. Antibiotic production by actinomycetes in soil demonstrated by morphological changes induced in Helminthosporium sativum. Nature 174:598-599.

129. Stolwijk, J. A. J., and K. V. Thimann. 1957. On the uptake of carbon dioxide and bicarbonate by roots, and its influence on growth. Plant Physiol. 32:513-520.

130. Stowe, B. B., F. H. Stodola, T. Hayashi, AND P. W. Brian. 1961. The early history of Gibberellin research. Intern. Conf. Plant Growth Regulation, 4th, p. 465-471. Iowa State University Press, Ames.

131. Stowe, B., AND T. Yamaki. 1957. The history and physiological action of the Gibberellins. Ann. Rev. Plant Physiol. 8:181-216.

132. SwABY, R. J. 1942. Stimulation of plant growth by organic matter. J. Australian Inst. Agr. Sci. 8:156-163.

133. Takahashi, N., ANd R. Curtis. 1961. Isolation and characterization of malformin. Plant Physiol. 36:30-36.

134. Taylor, G. S., and J. H. Abrahams. 1953. A diffusion-equilibrium method for obtaining soil gases under field conditions. Soil Sci. Soc. Am. Proc. 17:201-206.

135. Truog, E., ANd J. Sykora. 1917. Soil constituents which inhibit the action of plant toxins. Soil Sci. 3:333-351.

136. ValleaU, W. D., ANd E. M. Johnson. 1927. Tobacco frenching-a nitrogen deficiency disease. Kentucky Agr. Expt. Sta. Bull. 281:179-253.

137. Waksman, S. A., and R. L. Starkey. 1931. The soil and the microbe, p. 159. John Wiley \& Sons, Inc., New York.

138. Wensley, R. N. 1956. The peach replant problem in Ontario. IV. Fungi associated with replant failure and their importance in fumigated and nonfumigated soils. Can. J. Botany 34:967-981.

139. Went, F. W., and K. V. Thimann. 1937. Phytohormones. Macmillan Co., New York.

140. Woods, F. W. 1960. Biological antagonisms due to phytotoxic root exudates. Botan. Rev. 26:546-569.

141. Wright, J. M. 1951. Phytotoxic effects of some antibiotics. Ann. Botany 15:493-499.

142. Wright, J. M. 1954. The production of antibiotics in soil. I. Production of gliotoxin by Trichoderma viride. Ann. Appl. Biol. 41:280-289.

143. Wright, J. M. 1956. The production of antibiotics in soil. IV. Production of antibiotics in coats of seeds sown in soil. Ann. Appl. Biol. 44:561-566.

144. Wright, J. M. 1956. Production of gliotoxin in soils. Nature 177:896.

145. Young, J. L., and J. L. Mortensen. 1958. Soil nitrogen complexes. I. Chromatography of amino compounds in soil hydrolysates. Ohio Agr. Expt. Sta. Res. Circ. 61: 1-18. 


\section{ERRATUM}

\section{PHYTOTOXIC SUBSTANCES FROM SOIL MICROORGANISMS AND CROP RESIDUES}

T. M. MCCALla and F. A. HASKINS

Soil and Water Conservation Research Division, U.S. Department of Agriculture, and Nebraska Agricultural Experiment Station, University of Nebraska, Lincoln, Nebraska

Volume 28 , no. 2, page 192, col. 2, line 21 : change "substances inhibitory to plant growth" to "substances stimulative to plant growth." 